\title{
Late Jurassic facies succession of the Kleszczów Graben area (southern border of the Łódź Depression, peri-Tethyan shelf, central Poland)
}

\author{
Piotr OLCHOWY ${ }^{1, *}$, Marcin KRAJEWSKI ${ }^{1}$ and Ireneusz FELISIAK ${ }^{1}$ \\ 1 AGH University of Science and Technology, Faculty of Geology, Geophysics and Environmental Protection, \\ Al. A. Mickiewicza 30, 30-059 Kraków, Poland
}

Olchowy, P., Krajewski, M., Felisiak, I., 2019. Late Jurassic facies succession of the Kleszczów Graben area (southern border of the Łódź Depression, peri-Tethyan shelf, central Poland). Geological Quarterly, 63 (4): 657-681, doi: 10.7306/gq.1496

Associate Editor: Anna Wysocka

Numerous fully cored boreholes completed in the last years in central Poland (Kleszczów Graben area, southern border of the Łódź Depression) enabled the researchers to obtain new sedimentological data on the Oxfordian-Tithonian continuous sedimentary record in the Polish part of the northern Tethys shelf. Twenty-two facies were distinguished in the sedimentological succession. The facies represent the outer-, mid- and inner-ramp environments, including evaporitic episodes and palaeosols. The facies document that the Oxfordian-Lower Kimmeridgian (up to Hypselocyclum) carbonate ramp has evolved to the Upper Kimmeridgian-Tithonian carbonate-siliciclastic ramp. Among the Kimmeridgian deposits, numerous hardgrounds, tidal channel deposits and gravity flow sediments were identified. The Kleszczów Graben sedimentary succession is discussed along with the lithostratigraphical units known from the adjacent regions of southern and central Poland.

Key words: Late Jurassic, outer-inner ramp facies, Oxfordian, Kimmeridgian, Tithonian, North Tethys Shelf.

\section{INTRODUCTION}

During the Late Jurassic, in central and southern Poland, carbonate and carbonate-siliciclastic deposition occurred in an epicontinental sea that bordered the Tethys Ocean from the north (e.g., Ziegler, 1990; Kutek, 1994; Matyszkiewicz, 1997; Golonka, 2004). The area of central and southern Poland formed in general a gently inclined and extensive carbonate ramp within the northern Tethyan shelf (e.g., Gutowski et al., 2005; Gutowski, 2006). The range of the epicontinental sea generally decreased during Kimmeridgian and Tithonian times (Niemczycka and Brochwicz-Lewiński, 1988). The most important factors controlling deposition in this area were sea level changes, elevations of the Paleozoic basement, and synsedimentary tectonics (e.g., Kutek, 1994; Gutowski et al., 2005; Matyszkiewicz et al., 2006, 2012, 2016; Krajewski et al., 2011a, 2016). Generally, the Jurassic sedimentation in Poland is represented by three transgressive-regressive tectono-stratigraphic units (Kutek, 1994):

* Corresponding author, e-mail: piotr.olchowy@agh.edu.pl Received: June 27, 2018; accepted: June 21, 2019; first published online: November 25, 2019
- the COK Sequence (Callovian, Oxfordian and Lower Kimmeridgian), whose upper boundary is placed near the top of the Hypselocyclum Zone;

- the LUK Sequence (Lower and Upper Kimmeridgian) with the upper boundary within the Eudoxus Zone,

- the KVB Sequence (topmost Kimmeridgian, Tithonian/"Volgian" and Lower Berriasian). These sequences include:

- Callovian and Lower Oxfordian transgressive siliciclastic and marly deposits,

- Middle Oxfordian-Tithonian mainly carbonate and carbonate-siliciclastic deposits,

- Purbeckian-type facies deposited during the Tithonian and Early Berriasian.

In Poland, the Upper Jurassic-lowermost Cretaceous sedimentary sequence attained a maximum thickness of $\sim 1300 \mathrm{~m}$ in the Carpathian Foredeep (e.g., Niemczycka and Brochwicz-Lewiński, 1988; Kutek, 1994; Gutowski et al., 2005; Matyja, 2009; Krajewski et al., 2011a). The stratigraphic subdivision of Upper Jurassic deposits in Poland is based mostly on biostratigraphic data and numerous lithostratigraphic units (e.g., Malinowska, 1967; Matyja, 1977, 2009, 2011; Dembowska, 1979; Kutek, 1994; Gutowski, 1998; Olszewska et al., 2012; Wierzbowski, 2017; and references therein).

In the last years, the possibility has appeared to study the hundreds-of-metres thick Upper Jurassic sedimentary sequence from the Kleszczów Graben area in central Poland based on fully cored boreholes. The boreholes were drilled in the 


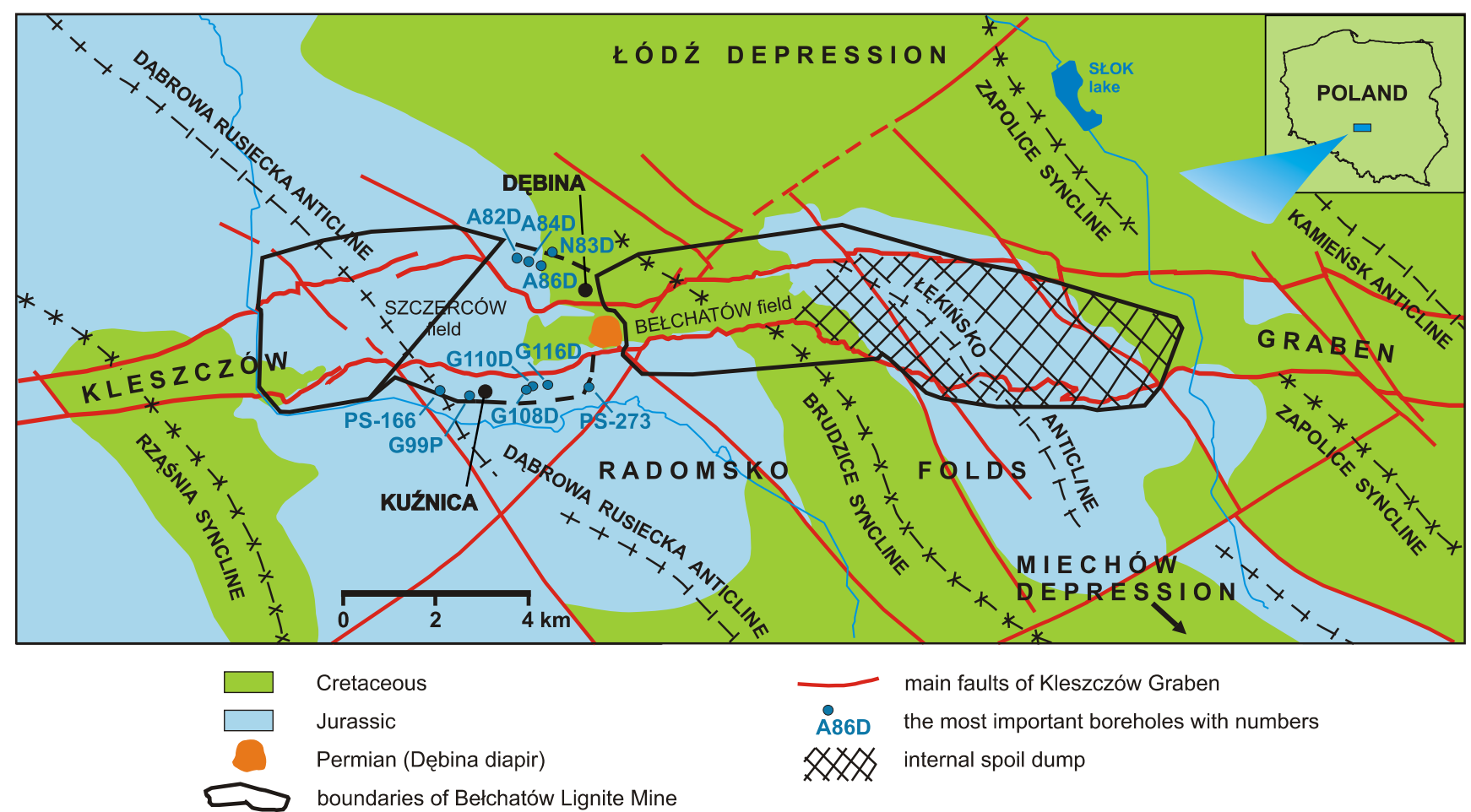

Fig. 1. Geological map of the Kleszczów Graben area with position of the most important investigated boreholes

Kleszczów Graben area located at the boundary of the Łódź and Miechów depressions (Fig. 1). The paper aims to present the Upper Jurassic sedimentary sequence based upon the facies analysis, which reflects the evolution of the Polish part of the northern Tethys shelf. The location of the study area within the border zone between other occurrences of Upper Jurassic sediments and the detailed characterization of sedimentary successions are key elements of regional comparative studies leading to the reconstruction of ramp evolution.

\section{MATERIALS AND METHODS}

The study materials were the cores from 26 representative boreholes drilled in the Kleszczów Graben area, $\sim 20 \mathrm{~km}$ south-west of Bełchatów (Fig. 1). They originated from the longest boreholes drilled into the Dąbrowa Rusiecka Anticline, in which Upper Jurassic sediments were not faulted and where the stratal dips did not exceed several degrees (Figs. 2-4). Particularly important were the boreholes completed in 2015-2017 and data from the archival boreholes kindly provided by the geological staff of the Bełchatów Lignite Mine. The boreholes were drilled in a grid density changing from several hundred to several tens of metres. Most of them were located concordantly with the slope of the anticline limb, which enabled us to observe progressively younger Upper Jurassic strata along the distance from Kuźnica towards Dębina villages (Fig. 1). The boreholes in which higher thicknesses of particular facies were related to tectonic inclination of sediments at the edge of the Kleszczów Graben were excluded from the analysis. The maximum thickness of Upper Jurassic strata in the individual boreholes was 290 m (Figs. 2-4). The comprehensive lithostratigraphic column of the Upper Jurassic succession was compiled based upon the dense grid of boreholes, supported by a lithological correlation of repeating characteristic sedimentary sequences observed in the adjacent boreholes.

The basic research method was microfacies analysis, which included lithofacies descriptions of boreholes and identification of sedimentary structures and rock textures, as well as core sampling for thin and polished sections, and photographic documentation. Some samples were studied under the Scanning Electron Microscope and X-ray diffraction (XRD) in order to identify the minerals. These enabled lithostratigraphic correlations of the drilling cores of Upper Jurassic sediments of neighbouring areas, whereas the biostratigraphical data has been adopted from other authors by correlating the distinguished facies with the existing lithostratigraphic formations and units dated in adjoining areas based on outcrops and boreholes (e.g., Głowniak, 1991; Kutek, 1994; Kutek and Zeiss, 1997; Wierzbowski, 2017 and references therein). The biostratigraphic data from foraminifers and calcareous dinocysts yielded only general information about age of the sediments, ranging from Oxfordian to Tithonian or even Lower Cretaceous (Olszewska and Kowal-Kasprzyk, pers. comm., 2013, 2019).

\section{UPPER JURASSIC SEDIMENTARY SUCCESSION OF THE KLESZCZÓW GRABEN AREA}

\section{FACIES SUCCESSION OF THE SOUTHERN BORDER OF THE ŁÓDŹ DEPRESSION (KLESZCZÓW GRABEN AREA)}

The results presented in this paper show a change in the vertical succession of characteristic facies related to the evolution of the Upper Jurassic carbonate ramp in the Polish part of 


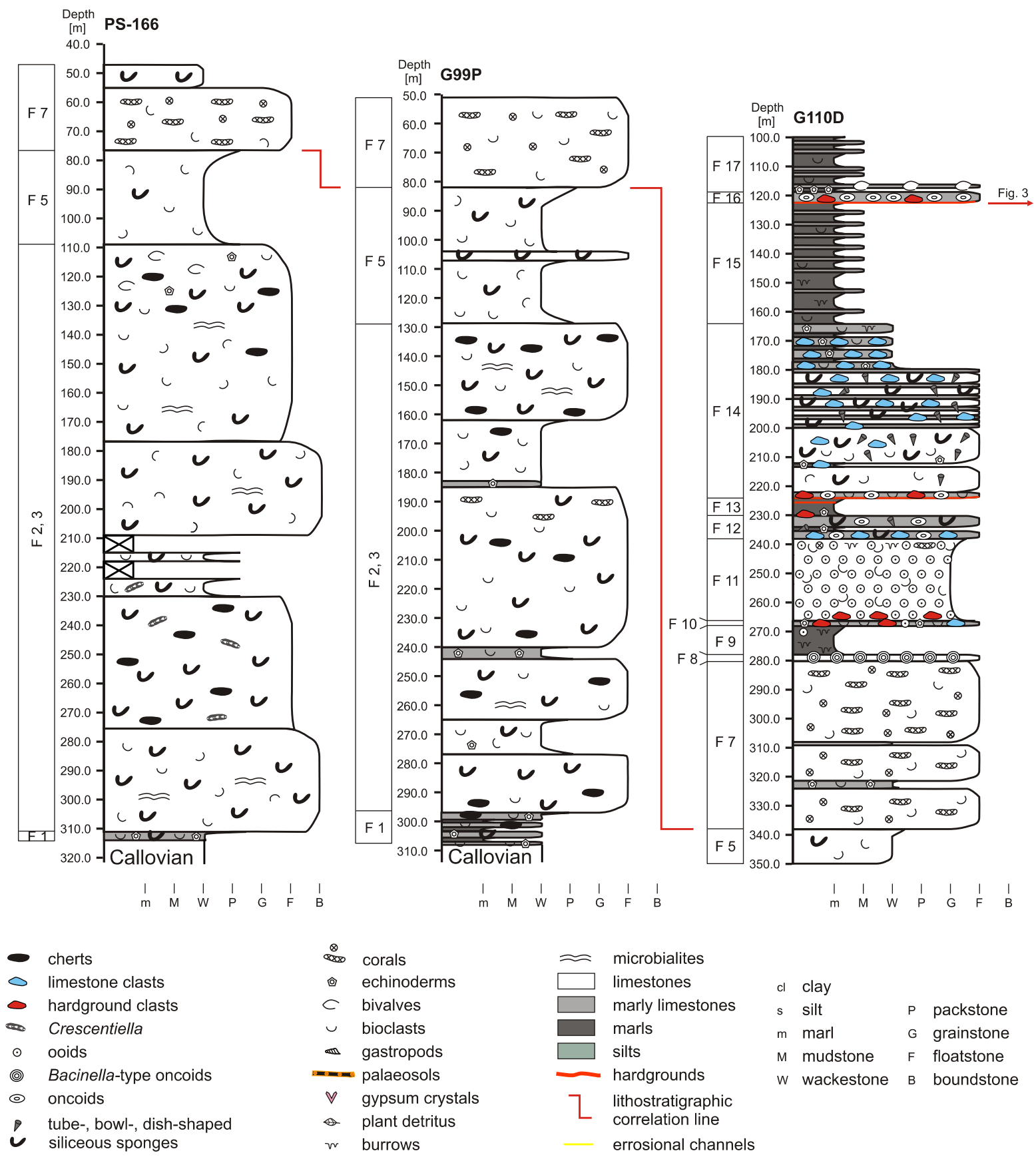

Fig. 2. Examples of lithological columns of Upper Jurassic sediments from the study area 


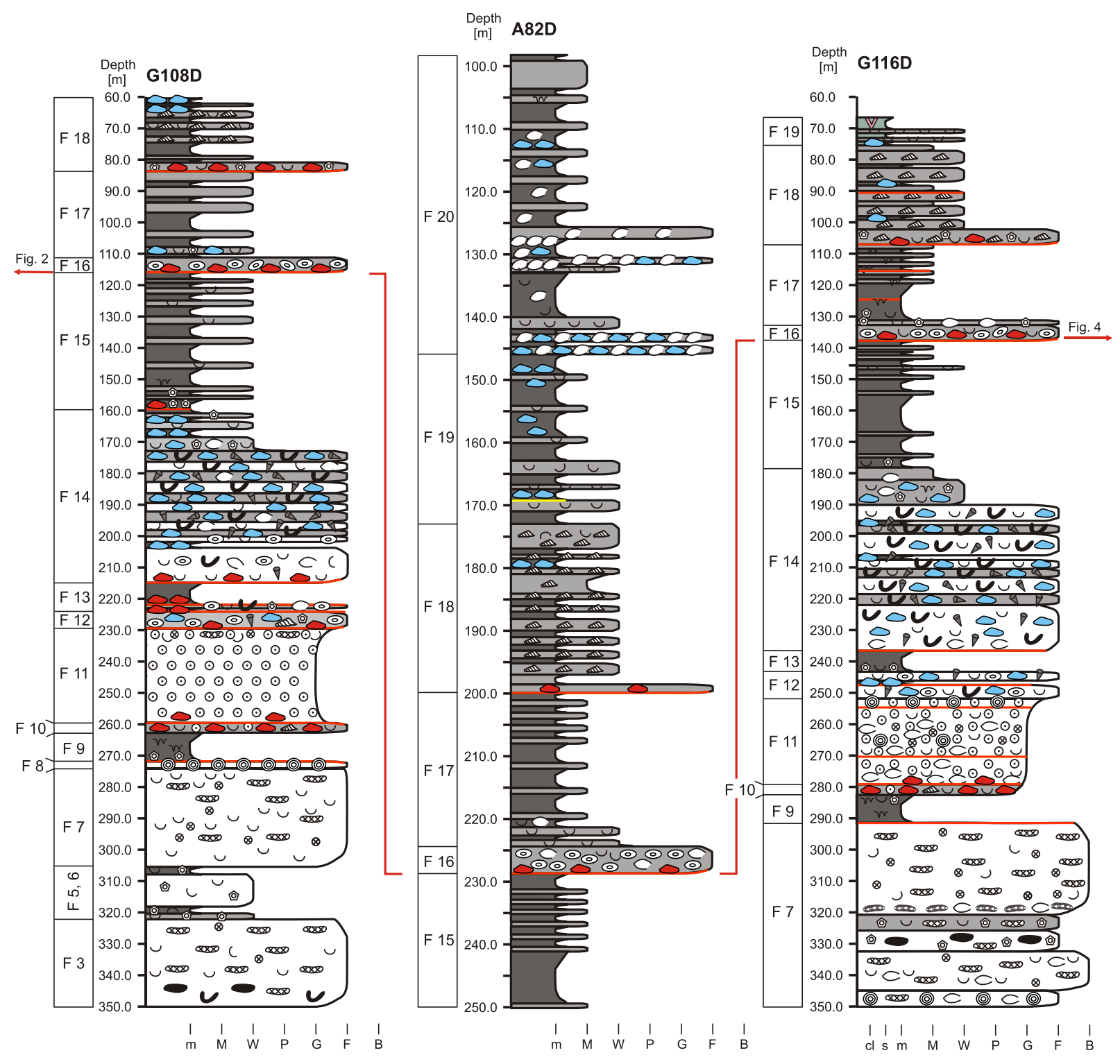

Fig. 3. Examples of lithological columns of Upper Jurassic sediments from the study area

For explanations see Figure 2

the northern Tethys shelf. Generally, 22 facies were distiguished (Figs. 6-13 and Table 1). The facies and its thicknesses characterize the lithological units distinguished by the authors of this paper (Fig. 5). Those units are correlated with lithostratigraphic units of central Poland presented by other authors. Characteristic features of the facies, main components and maximum thicknesses are presented in Table 1.

\section{SPONGE MARLY LIMESTONES AND MARLS (F1)}

The oldest Upper Jurassic sediments encountered in the examined drill boreholes are Lower and Middle Oxfordian alternating grey and dark grey sponge-marly limestones, marls and sometimes sponge limestones, up to $\sim 10 \mathrm{~m}$ in thickness, which directly overlie the clastic-carbonate Callovian strata (Figs. 2, $6 \mathrm{~A}, \mathrm{~B}$ and Table 1). The sponge-marly limestones and sponge limestones contain numerous calcified platy Lithistida and Hyalospongea sponges up to $1 \mathrm{~cm}$ thick (cf. Trammer, 1982), entirely or partly pyritized, as well as tuberoids (up to $\sim 2 \mathrm{~cm}$ in size, Fig. 6A, B). The marls are several centimetres thick and host tuberoids, fragments of bryozoans (up to $0.5 \mathrm{~cm}$ in size), ammonites and clay laminae (Fig. 6B).

Facies interpretation: the F1 sediments are interpreted as the Lower-Middle Oxfordian mid-outer ramp facies. The sponge limestones represent sponge biostromes and/or cluster and segment reefs (sensu Riding, 2002; Matyszkiewicz et al., 2012) or sponge bioherms (sensu Trammer, 1982).

\section{SPONGE LIMESTONES WITH CHERTS (F2),} AND MICROBIAL-SPONGE LIMESTONES (F3)

The combined thickness of F2 and F3 facies reaches $180 \mathrm{~m}$ (Figs. 2 and 5). The sponge limestones with cherts (F2) are 


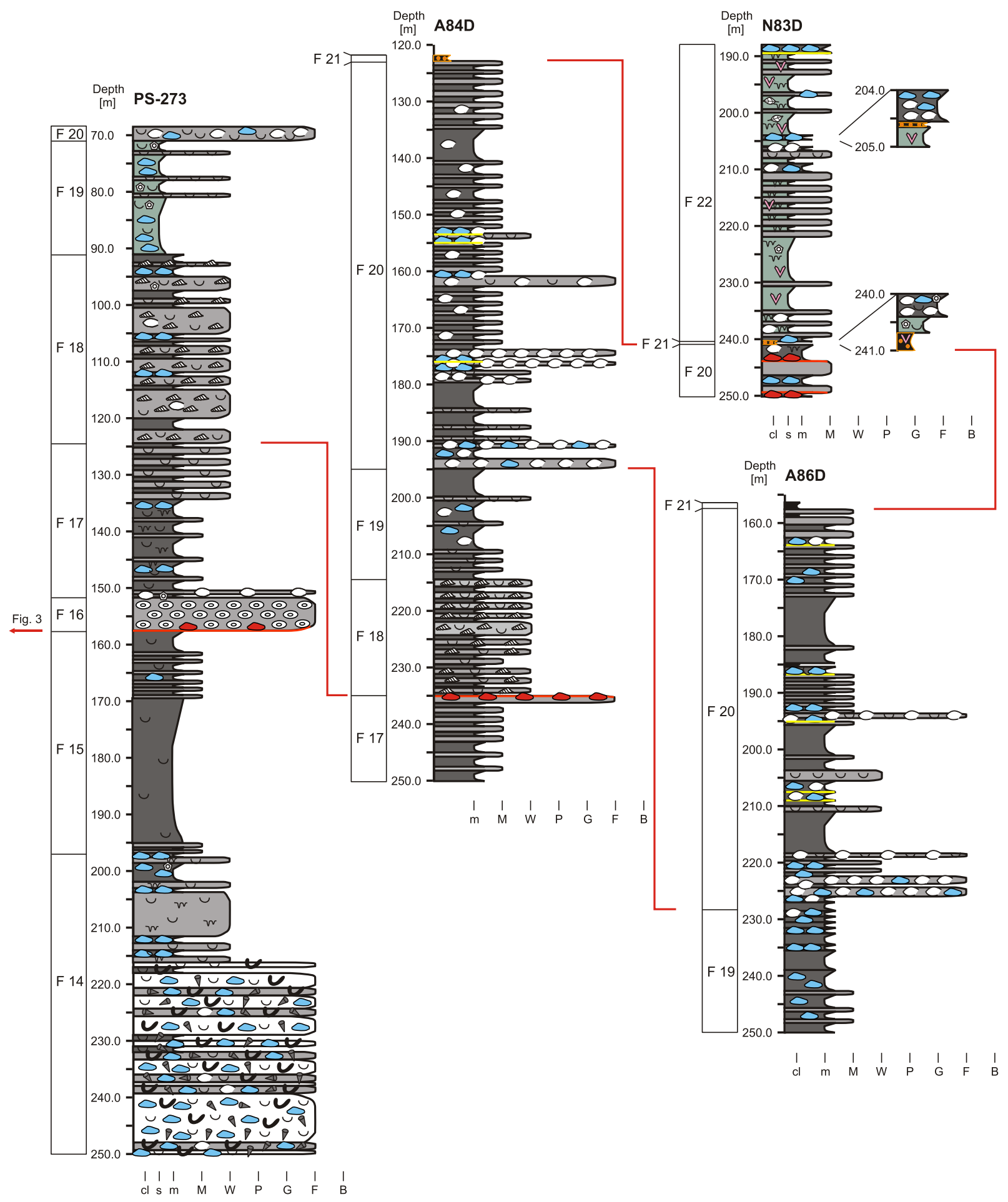

Fig. 4. Examples of lithological columns of Upper Jurassic sediments from the study area

For other explanations see Figure 2 


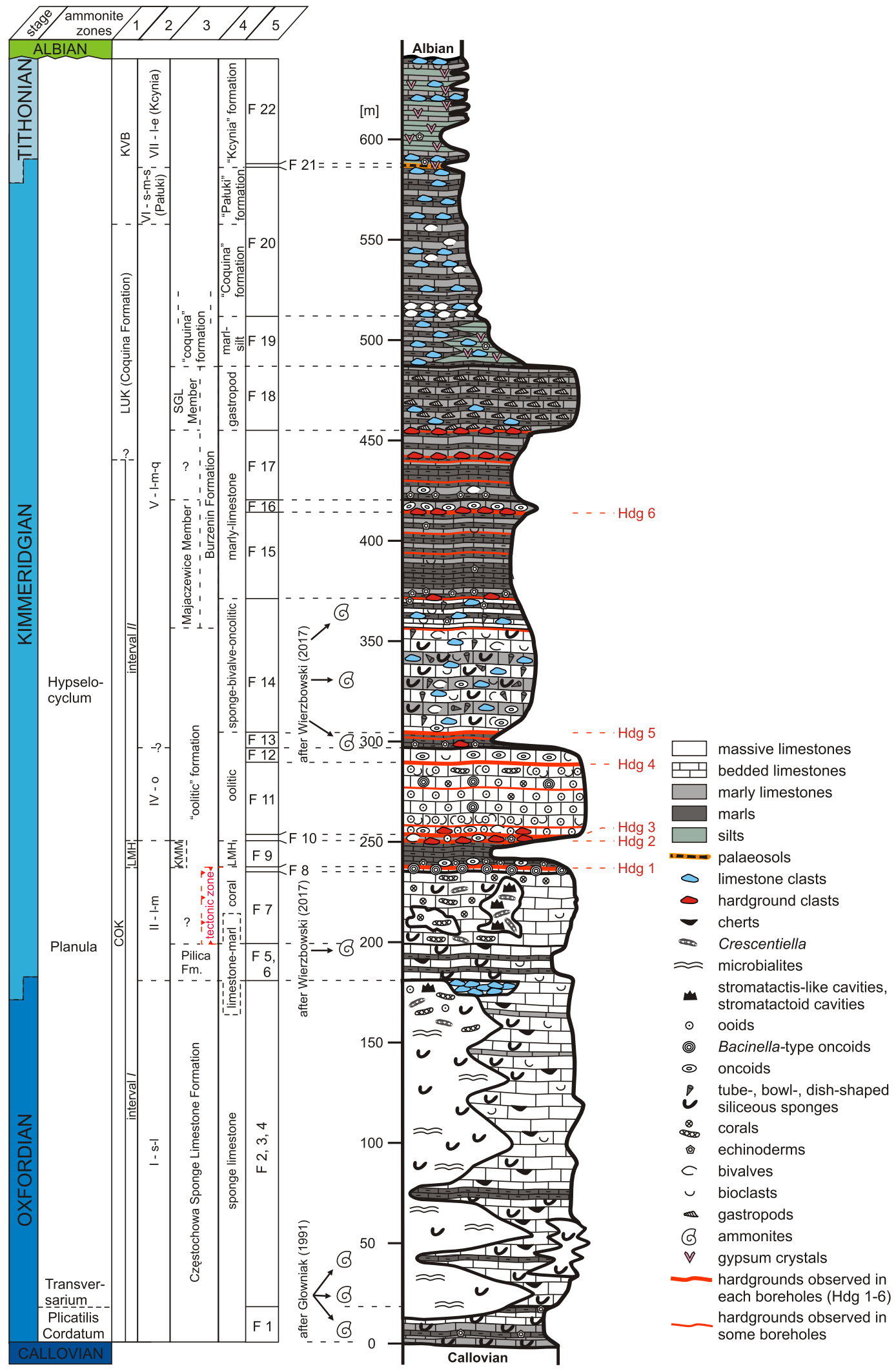

Fig. 5. Generalized lithostratigraphic column of Upper Jurassic sediments of the Kleszczów Graben area with sequences, formations and units distinguished in central Poland by other authors (columns 1-3), and our lithological units (column 4)

1 - tectono-stratigraphic units after Kutek (1994): COK Sequence, LUK Sequence, KVB Sequence; LMH - Lowermost Marly Horizon; 2 - lithostratigraphic subdivision of the formations after Dembowska (1979): I - s-I - spongy-limestone, II - I-m - limestone-marly; IV - o - oolitic, V - I-m-q - limestone-marly-coquina; VI - s-m-s - shale-marly-siltstone (Pałuki) and VII - I-e limestone-evaporitic (Kcynia); 3 - lithostratigraphic units of the Szczerców brown-coal field after Wierzbowski (2017; Figs. 5, 12 and 13): KMM - Kiełczygłów Marl Member, SGL - Sarnów Gastropod Limestone Member; 4 - lithological units proposed by the present authors (cf. Barwicz-Piskorz, 1992); biostratigraphic data after Głowniak (1991) and Wierzbowski (2017); 5 - facies succession based on studied boreholes 
beige medium- to thick-bedded sediments composed of siliceous sponges, microbialites (thrombolites, stromatolites) and Crescentiella (a new name for Tubiphytes morronensis Crescenti; Senowbari-Daryan et al., 2008), but the essential components are bioclasts of echinoderms, bivalves, brachiopods, and serpulids or bryozoans, forming the bioclastic wackestones-packstones matrix (Table 1). Common are tuberoids, peloids and benthic foraminifers. Characteristic for these limestones are numerous cherts, up to several centimetres in size.

The microbial-sponge limestones (F3) are beige massive rocks dominated by calcified, platy, siliceous sponges and microbial structures (mainly clotted and layered thrombolites), and peloidal or agglutinated stromatolites. Sponges are commonly overgrown by microbialites, mainly laminated thrombolites forming the sponge-thrombolite association of the rigid framework. The intraframework spaces are entirely or partly filled with wackestones containing bioclasts of tuberoids, serpulids, echinoderms and bivalves or Crescentiella. Common are geopetal infillings as well as stromatactis-like cavities (sensu Matyszkiewicz, 1997) and stromatactoid cavities (sensu Neuweiler et al., 2001; Fig. 6C). The uppermost part of facies F3 hosts numerous Crescentiella, Microsolena platy corals, and rare ooids (Fig. 7A).

In their lower and middle parts, both the F2 and F3 facies embrace intercalations of marly limestones and marls with numerous echinoderm fragments and single limestone clasts. Locally, these sediments form repeating layers ranging from several centimetres to several metres in thickness. The marly limestone layers are more common and thicker than the marls.

Facies interpretation: the sponge limestones with cherts (F2) are medium- to thick-bedded organodetrital and biostromal facies. The microbial-sponge limestones (F3) represent a massive frame reef (sensu Riding, 2002) with borings and numerous growth cavities with geopetal infillings. These mid-ramp facies belong to the typical microbial-sponge sediments widely distributed over the northern Tethys shelf (e.g., Leinfelder et al., 1996; Matyszkiewicz, 1997; Olóriz et al., 2003). The development of biostromes and microbial-sponge reefs was periodically halted, as revealed by the presence of repeating layers of marly limestones with common nodular structure, up to several tens of centimetres thick. Both the F2 and F3 sediments represent microbial-sponge facies of the Upper Oxfordian mid-ramp environment, located between the normal and the storm wave bases, generally interpreted as reaching down to $\sim 100 \mathrm{~m}$ depth (e.g., Leinfelder et al., 1996; Matyszkiewicz et al., 2006; Krajewski et al., 2018). The occurrence of stromatactis-like cavities, numerous Crescentiella, and relatively deep-water platy Microsolena in the upper part of F3 can be compared to the similar facies located between normal and storm wave bases (e.g., Leinfelder et al., 1996; Olchowy, 2011; Matyszkiewicz et al., 2012; Krajewski and Schlagintweit, 2018).

\section{GRAVITY FLOW DEPOSITS (F4)}

This facies attains a thickness of up to $10 \mathrm{~m}$ (Fig. 5). It did not occur in all the studied drill cores, but was found only near the Kleszczów Graben edges. The boundaries between facies F4 and F2/F3 are erosional. The gravity flow deposits consist of random-size particles, ranging from clasts of various sizes (millimetres to a few centimetres across, probably even to metre-scale blocks) to fine-grained calcisiltites (Fig. 6D and Table 1). The clasts are randomly distributed and decrease in size up the sequence. They are angular or subangular, and composed of fragments of sponge limestones (F2) and micro- bial-sponge limestones (F3). Up the sequence, the breccias grade into calciturbidites with Bouma-type divisions, excluding the convolute lamination (Fig. 6D).

Facies interpretation: the F4 facies comprises debrites and calciturbidites (e.g., Flügel, 2004). Their presence in narrow zones beyond the edges of the Kleszczów Graben indicates synsedimentary tectonic activity along steep, tectonically controlled scarps. In general, the tectonic movements in the grabens were usually the main factors triggering the sediment-gravity flows (e.g., Flügel, 2004; Montenat et al., 2007). In Upper Jurassic deposits from central and southern Poland, gravity flow deposits (olistoliths, debrites etc.) deposited along grabens active in the Late Jurassic were described in several areas (e.g., Marcinowski, 1970; Kutek, 1994; Matyszkiewicz, 1996, 1997; Ziółkowski, 2007; Krajewski et al., 2016; Woźniak et al., 2018).

FINE GRAINED AND PELITIC LIMESTONES (F5), MARLY LIMESTONES AND MARLS (F6)

The F5 facies includes cream-coloured, dark grey or grey, mostly pelitic limestones (mainly wackestone-mudstone) with numerous, sometimes large-canal burrows and bioclasts (Figs. 2, 3 and 7B). Sometimes calcified siliceous sponges occurred. The F6 facies comprises intercalations of marly limestones and marls with abundant crinoids and clasts of marly limestones (Figs. 2, 3 and Table 1). The thickness of the facies does not exceed $10 \mathrm{~m}$, being usually $\sim 2 \mathrm{~m}$. The contact of facies F5/F6 and F2/F3 is usually distinct and marked by the appearance of pseudonodular structure in marly limestones or in marls. The pseudonodules (up to $\sim 10 \mathrm{~cm}$ across) are surrounded by dark grey marl laminae and layers (up to several centimetres thick) with numerous crinoids and bryozoans. Locally, the marly limestones do not show nodular structure but have diffuse clay streaks. Up the sequence, both the F5 and F6 facies grade into the coral and pelitic limestones of facies F7.

Facies interpretation: fine-grained and pelitic limestones (F5), as well as marly limestones and marls (F6), represent outer-ramp sediments (e.g., RMF 2, 3; Flügel, 2004) and document the supression of the growth of Oxfordian microbial-sponge reefs and biostromes of facies F2 and F3 due to inundation of the ramp.

\section{CORAL AND PELITIC LIMESTONES (F7)}

The F7 sediments reach $\sim 35 \mathrm{~m}$ in thickness (Figs. 2, 3, 5 and Table 1). The succession starts with microbial-sponge limestones, up to several metres thick, which grade up the sequence into porous limestones, in which siliceous sponges are gradually replaced by platy Microsolena corals and calcareous sponges, including the chaetetids. In the upper part of the F7 succession, the Microsolena corals are replaced by massive, phaceloidal and branched coral colonies (Figs. 6E and 7C, D). The Microsolena corals are surrounded by grey or cream-coloured bioclastic wackestones and packstones built of fragments of corals, bivalves, echinoderms and serpulids (Fig. 7C and Table 1) with some admixture of clay matter, either dispersed in bioclastic matrix or forming laminae, up to $1 \mathrm{~mm}$ thick. Commonly observed is the rigid framework forming frame reefs (sensu Riding, 2002) with growth cavities (Fig. 6E). The coral framestones are accompanied by biodetrital limestones or pelitic limestones, sometimes containing single chert nodules (up to several centimetres across). In some drill cores, pelitic 
Facies, fabric, main components and characteristic features of the Upper Jurassic sediments from the Kleszczów Graben area

\begin{tabular}{|c|c|c|c|c|}
\hline Facies & $\frac{0}{\frac{0}{20}}$ & $\begin{array}{l}\text { Characteristic } \\
\text { components }\end{array}$ & $\begin{array}{l}\text { Characteristic } \\
\text { features }\end{array}$ & 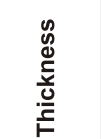 \\
\hline $\begin{array}{l}\text { F1: Sponge marly } \\
\quad \text { limestones and marls }\end{array}$ & $\begin{array}{l}\mathbf{W} \\
\mathrm{F}\end{array}$ & $\begin{array}{l}\text { Siliceous sponges (Lithistida, Hyalospon- } \\
\text { gea); tuberoids; bryozoa; ammonites }\end{array}$ & Thin-bedded facies; platy sponges; marl intercalations & $10 \mathrm{~m}$ \\
\hline $\begin{array}{l}\text { F2: Sponge limestones with } \\
\text { cherts } \\
\text { F3: Microbial-sponge } \\
\quad \text { limestones }\end{array}$ & $\begin{array}{l}\text { W } \\
\text { F } \\
\text { P } \\
\text { Fr } \\
\text { Fr } \\
\text { W } \\
P \\
\text { G }\end{array}$ & $\begin{array}{l}\text { Siliceous sponges; tuberoids; stromatolites; } \\
\text { brachiopods; echinoderms; Crescentiella; } \\
\text { bioclasts; serpulids; benthic foraminifers } \\
\text { Siliceous sponges; tuberoids; bioclasts; } \\
\text { brachiopods; echinoderms; Crescentiella; } \\
\text { stromatolites; thrombolites; platy corals; } \\
\text { benthic foraminifers }\end{array}$ & $\begin{array}{l}\text { Medium-thick facies; rare marl intercalations in lower and middle } \\
\text { parts; cherts } \\
\text { Massive facies; rigid framework; growth cavities; high lateral } \\
\text { fabric diversity (lenses of biodetrital or pelitic limestone); } \\
\text { stromatactis-like cavities in the upper part }\end{array}$ & $180 \mathrm{~m}$ \\
\hline F4: Gravity flow deposits & $\begin{array}{l}\text { R, F } \\
\text { W, P } \\
\text { G, M }\end{array}$ & Clasts of eroded F2, F3 & Breccias; debris flow; calciturbidites; Bouma sequence & $\sim 0-10 \mathrm{~m}$ \\
\hline $\begin{array}{l}\text { F5: Fine-grained and pelitic } \\
\text { limestones } \\
\text { F6: Marly limestones and } \\
\text { marls }\end{array}$ & $\begin{array}{l}\mathbf{M} \\
\mathbf{W} \\
\mathrm{P} \\
\mathbf{M} \\
\mathbf{W} \\
\mathbf{m}\end{array}$ & $\begin{array}{l}\text { Bioclasts; crinoids; echinoderms; bryozoa; } \\
\text { spicules; benthic foraminifera; filaments; } \\
\text { peloids; Saccocoma; cherts; rare sponges } \\
\text { Echinoderms; crinoids; bryozoa; bioclasts; } \\
\text { filaments; marly limestone clasts; rare } \\
\text { microsolenids }\end{array}$ & $\begin{array}{l}\text { Medium bedded facies; local nodular fabric; burrows; marl } \\
\text { intercalations } \\
\text { Burrows; inclination up to } 20^{\circ} \text { (close to the Kleszczów Graben), } \\
\text { marly limestone clasts in marly matrix }\end{array}$ & $17 \mathrm{~m}$ \\
\hline $\begin{array}{l}\text { F7: Coral and pelitic } \\
\text { limestones }\end{array}$ & $\begin{array}{l}\text { F } \\
\text { B } \\
\text { Fr } \\
\text { W }\end{array}$ & $\begin{array}{l}\text { Platy; massive and branchy corals; } \\
\text { calcareous sponges (including Chaetetids); } \\
\text { Crescentiella; gastropods; algaes; bivalves; } \\
\text { echinoderms; mirobialites; local Bacinella- } \\
\text { type oncoids }\end{array}$ & $\begin{array}{l}\text { Thick-bedded and massive facies; high porosity; common } \\
\text { sponges in the lower part; single cherts in the lower and middle } \\
\text { parts; stromatactis-like cavities }\end{array}$ & $35 \mathrm{~m}$ \\
\hline $\begin{array}{l}\text { F8: Bacinella-type oncoid } \\
\text { limestones } \\
\text { Hardground } 1\end{array}$ & $\begin{array}{l}\mathbf{F} \\
\mathrm{R}\end{array}$ & $\begin{array}{l}\text { Bacinella-type oncoids; fine oncoids; } \\
\text { numerous bioclasts (echinoderms, bivalves, } \\
\text { gastropods, corals) }\end{array}$ & $\begin{array}{l}\text { Porous and oval Bacinella-type oncoids up to } 3 \mathrm{~cm} \text { in diameter; } \\
\text { microscopic scale hardgrounds; marly upper part }(0.3 \mathrm{~m}) \text { with } \\
\text { burrows and numerous non-porous, oval and elliptical oncoids } \\
\text { up to } 2 \mathrm{~cm}\end{array}$ & $3 \mathrm{~m}$ \\
\hline $\begin{array}{l}\text { F9: Marls and marly } \\
\quad \text { limestones } \\
\text { Hardground } 2\end{array}$ & m & Rare crinoids; oncoids and bioclasts & $\begin{array}{l}\text { Thin-bedded facies; burrows with diffuse countours; numerous } \\
\text { crinoids and sometimes oncoids and bivalves in the lowermost } \\
\sim 0.7 \text { m part; hardgrounds in the lower and upper boundaries; } \\
\text { marly limestone with numerous burrows and clasts in the } \\
\text { upper } \sim 2 \text { m part }\end{array}$ & $13 \mathrm{~m}$ \\
\hline $\begin{array}{l}\text { F10: Clastic-bioclastic } \\
\text { marly limestones } \\
\text { Hardground } 3\end{array}$ & $\mathbf{F}$ & $\begin{array}{l}\text { Marl and marly limestone clasts; bivalves; } \\
\text { echinoderms; ooids; gastropods }\end{array}$ & $\begin{array}{l}\text { Clasts with numerous dispersed fine bioclasts (echinoderms, } \\
\text { bivalves) and foraminifers; matrix surrounding the clasts with } \\
\text { bivalves, echinoderms and pyritized ooids }\end{array}$ & $3.5 \mathrm{~m}$ \\
\hline $\begin{array}{l}\text { F11: Oolitic limestones } \\
\text { Hardground } 4\end{array}$ & $\begin{array}{l}\text { G } \\
F \\
P\end{array}$ & $\begin{array}{l}\text { Ooids; aggregate grains; bioclasts } \\
\text { (bivalves, echinoderms, corals, gastropods, } \\
\text { bryozoa), subordinately oncoids, calcareous } \\
\text { algaes and sponges; Bacinella-type } \\
\text { oncoids; clasts }\end{array}$ & $\begin{array}{l}\text { Thick-bedded facies; hardgrounds at the base and in the upper } \\
\text { boundary; hardground in the middle part; clasts at the base } \\
\text { and in the top; local accumulations of bivalves, corals and } \\
\text { Bacinella-type oncoids }\end{array}$ & $36 \mathrm{~m}$ \\
\hline F12: Oncolitic limestones & $\mathbf{F}$ & $\begin{array}{l}\text { Oncoids; gastropods; serpulids; bryozoa; } \\
\text { bioclasts; echinoderms; bivalves; clasts }\end{array}$ & Bored and encrusted hardground at the base & $7.5 \mathrm{~m}$ \\
\hline $\begin{array}{l}\text { F13: Marls } \\
\text { Hardground } 5\end{array}$ & $\mathrm{~m}$ & Crinoids; bivalves; bioclasts & $\begin{array}{l}\text { Thin-bedded facies; numerous crinoids, bivalves and clasts } \\
\text { in the lowermost } \sim 0.4 \mathrm{~m} \text {; rare burrows; hardgrounds in the } \\
\text { upper part and in the upper boundary; biodetrital limestone } \\
\text { bed with sharp boundaries up to } 0.5 \mathrm{~m} \text { in the lowermost part }\end{array}$ & $7.5 \mathrm{~m}$ \\
\hline $\begin{array}{l}\text { F14: Sponge-bivalve- } \\
\text { oncolitic limestones } \\
\text { and marly limestones }\end{array}$ & $\begin{array}{l}\mathbf{F} \\
\mathrm{R}\end{array}$ & $\begin{array}{l}\text { Siliceous sponges; bivalves; clasts; } \\
\text { tuberoids; oncoids; echinoderms; } \\
\text { bryozoans; gastropods; serpulids }\end{array}$ & $\begin{array}{l}\text { Thick-bedded facies; matrix with numerous bioclasts; rounded and } \\
\text { jagged shapes of sponges mostly in overturned positions; rounded } \\
\text { and irregular shapes of oncoids; common marly intervals; errosio- } \\
\text { nal channels with normal grading of clasts up to several cm; upper } \\
\text { part } \sim 10-15 \text { m contain numerous limestone clasts with rare } \\
\text { sponges within marly-bioclastic matrix or biodetrital limestone } \\
\text { with single marl intervals; ammonites in the uppermost part }\end{array}$ & $75 \mathrm{~m}$ \\
\hline
\end{tabular}


Tab. 1 cont.

\begin{tabular}{|c|c|c|c|c|}
\hline Facies & $\frac{0}{\frac{0}{2}}$ & $\begin{array}{l}\text { Characteristic } \\
\text { components }\end{array}$ & $\begin{array}{l}\text { Characteristic } \\
\text { features }\end{array}$ & 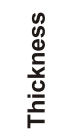 \\
\hline $\begin{array}{l}\text { F15: Marls and marly } \\
\text { limestones } \\
\text { Hardground } 6\end{array}$ & $\begin{array}{l}m \\
M \\
F\end{array}$ & Rare bioclasts and clasts & $\begin{array}{l}\text { Thin bedded facies; mainly marl with subordinate marly limestone; } \\
\text { numerous crinoids in the } \sim 3 \text { m lower part; hardgrounds with } \\
\text { borings in the middle and upper parts; local clasts up to several } \\
\mathrm{cm} \text { in the upper part; burrows; erosional upper boundary with } \\
\text { bored hardground; numerous borings filled with F16 on the last } \\
\sim 30 \mathrm{~cm} \text {; middle and upper parts }(\sim 15 \mathrm{~m}) \text { contain more marly } \\
\text { limestone intercalations up to } 30 \mathrm{~cm}\end{array}$ & $35 \mathrm{~m}$ \\
\hline F16: Oncolitic limestones & $\begin{array}{l}\mathbf{F} \\
\mathrm{R}\end{array}$ & $\begin{array}{l}\text { Oncoids; bivalves; echinoderms; } \\
\text { gastropods; bored and encrusted } \\
\text { hardground clasts; marly limestone clasts }\end{array}$ & $\begin{array}{l}\text { Well-sorted, numerous oval and elipsoidal partly pyritized oncoids } \\
\text { up to } 2 \mathrm{~cm} \text { in diameter with borings; bored and encrusted } \\
\text { hardground or hardground clasts } \sim 15 \mathrm{~cm} \text { above lower } \\
\text { boundary; marly beds up to } 30 \mathrm{~cm} \text { with numerous oncoids }\end{array}$ & $6 \mathrm{~m}$ \\
\hline $\begin{array}{l}\text { F17: Marly limestones and } \\
\text { marls }\end{array}$ & $\begin{array}{l}M \\
\mathbf{m} \\
\mathbf{W}\end{array}$ & $\begin{array}{l}\text { Crinoids; bioclasts; oncoids; echinoderms; } \\
\text { Crescentiella in the lowermost part; } \\
\text { sponge spicules; Saccocoma; filaments }\end{array}$ & $\begin{array}{l}\text { Thin-medium bedded facies; } 20 \mathrm{~cm} \text { marl with numerous } \\
\text { crinoids in the lower boundary; lower part consists mainly of } \\
\text { marl with marly limestone and limestone intecalations with } \\
\text { crinoids, clasts and oncoids; middle part is marl; upper part is } \\
\text { marl with marly limestone intercalations; local hardgrounds } \\
\text { (mainly in upper part); hardground with bored hardground clasts } \\
\text { in the upper boundary }\end{array}$ & $36 \mathrm{~m}$ \\
\hline $\begin{array}{l}\text { F18: Gastropod limestones, } \\
\text { marly limestones and } \\
\text { marls }\end{array}$ & $\begin{array}{l}\mathbf{F} \\
\mathbf{M} \\
\mathrm{W} \\
\mathrm{R}\end{array}$ & $\begin{array}{l}\text { Gastropods; bivalves; oysters; bioclasts } \\
\text { (common echinoderms); marly limestone } \\
\text { clasts }\end{array}$ & $\begin{array}{l}\text { Wavy laminae and beds from mm up to several } \mathrm{cm} \text { thick with } \\
\text { mass occurence of gastropods; beds up to several } \mathrm{cm} \text { thick with } \\
\text { dispersed gastropods; local brecciaction; desiccation cracks; } \\
\text { erosional surfaces; burrows; synsedimentary inclination } \sim 3^{\circ} \text {; } \\
\text { quartz grains }\end{array}$ & $31 \mathrm{~m}$ \\
\hline $\begin{array}{l}\text { F19: Marls, marly } \\
\text { limestones, silts }\end{array}$ & $\begin{array}{l}\text { M } \\
\mathbf{M}\end{array}$ & Limestone clasts & $\begin{array}{l}\text { Thin-bedded facies; erosional channels (numerous marly lime- } \\
\text { stone clasts surronded by marl in intervals up to } 0.8 \mathrm{~m} \text { in } \\
\text { thickness with sharp, commonly listrical shape bottom boundary); } \\
\text { fine gypsum crystals within silt; synsedimentary inclination } \sim 3^{\circ}\end{array}$ & $27 \mathrm{~m}$ \\
\hline $\begin{array}{l}\text { F20: Marls and marly lime- } \\
\text { stones with Nanogyra } \\
\text { accumulations }\end{array}$ & $\begin{array}{l}\mathbf{m} \\
\mathbf{M} \\
\mathbf{F}\end{array}$ & Nanogyra oyster; limestone clasts; bioclasts & $\begin{array}{l}\text { Mass occurence of oysters in marl up to some } m \text { thick in the } \\
\text { lower part; fragmentation of shells; chaotic shells arrangement }\end{array}$ & $72 \mathrm{~m}$ \\
\hline F21: Clays, palaeosols & cl & Plant detritus; quartz grains; clay clasts & $\begin{array}{l}\text { Clay laminae; brecciation; gypsum crystals; oval pores; } \\
\text { ferrigenous spots; local occurence of palaeosol up to } 0.1 \mathrm{~m} \text { thick }\end{array}$ & $1.5 \mathrm{~m}$ \\
\hline $\begin{array}{l}\text { F22: Silts, marly limestones } \\
\text { and marls }\end{array}$ & $\begin{array}{l}\mathrm{cl}, \\
\mathrm{M}, \\
\mathrm{m}\end{array}$ & $\begin{array}{l}\text { Limestone and marly limestone clasts; } \\
\text { plant detritus; quartz grains }\end{array}$ & $\begin{array}{l}\text { Erosional channels with numerous marly limestone clasts } \\
\text { surronded by marl in intervals up to } 1.5 \mathrm{~m} \text { (commonly up to } \\
0.6 \mathrm{~m} \text { ) in thickness with sharp, commonly listrical bottom } \\
\text { boundary; limestone clasts with numerous bioclasts in the } \\
\text { upper part; dispersed fine gypsum crystals within silt; burrows; } \\
\text { marly limestone beds } 0.1-0.5 \mathrm{~m} \text { in thickness }\end{array}$ & $52 \mathrm{~m}$ \\
\hline
\end{tabular}

limestones dominate, whereas corals are rather rare. Locally, in the top part of succession F7, Bacinella-type oncoids are dispersed, up to $\sim 3 \mathrm{~cm}$ in diameter. The F7/F8 transition is gradual and can be observed within a layer some tens of centimetres thick, where the amount of Bacinella-type oncoids increases at the expense of decreasing number of corals. Occasionally, the coral and pelitic limestones (F7) pass directly into marls (F9) (Fig. 8A).

Facies interpretation: the F7 facies represents transition from the mid-ramp to the inner-ramp environment (e.g., Flügel, 2004; Bádenas and Aurell, 2010). The lower part of succession F7 is dominated by microbial-sponge limestones deposited in the mid-ramp under low-energy conditions (Keupp et al., 1993; Olóriz et al., 2003). The presence of platy microsolenids among the siliceous sponges may suggest the ramp depth between 60 and $80 \mathrm{~m}$ (e.g., Insalaco, 1996). In the F7 sediments, Microsolena corals prevail, which suggests deposition in a mid-ramp setting (Leinfelder et al., 1996) below the normal wave base, in the lower photic zone under low-energy conditions and at low deposition rate (e.g., Insalaco, 1996; Lathuilière et al., 2005). Over time, the sedimentary environment has shallowed, as revealed by the presence of massive, phaceloidal and branching corals forming the coral reefs and/or biostromes. The successions with transitions from an assemblage of Microsolena-dominated corals to that embracing massive phaceloidal and branched corals are known from Upper Jurassic outcrops in central Poland (see Roniewicz and Roniewicz, 1971; Roniewicz, 2004; Frankowiak et al., 2019). The development of facies F7 resembles also the microsolenid biostromes wellknown from other localities in both northern and central Europe (see Insalaco, 1996). The appearance of biolithites, such as framestones and bafflestones, as well as Bacinella-type oncoids in the upper parts of succession F7 may indicate the inner-ramp, shallow-water environment, only some metres deep (e.g., Roniewicz and Roniewicz, 1971; Védrine, et al., 2007). The shallowing trend is confirmed also by still more common F8-type oncoids present in the top parts of succession F7.

\section{BACINELLA-TYPE ONCOID LIMESTONES (F8)}

The F8 facies (up to $3 \mathrm{~m}$ thick) (Figs. 2, 3, 5 and Table 1) comprises Bacinella-type oncoids, from several millimetres up to $\sim 3 \mathrm{~cm}$ in diameter (usually $1-3 \mathrm{~cm}$ ), embedded in the sedi- 

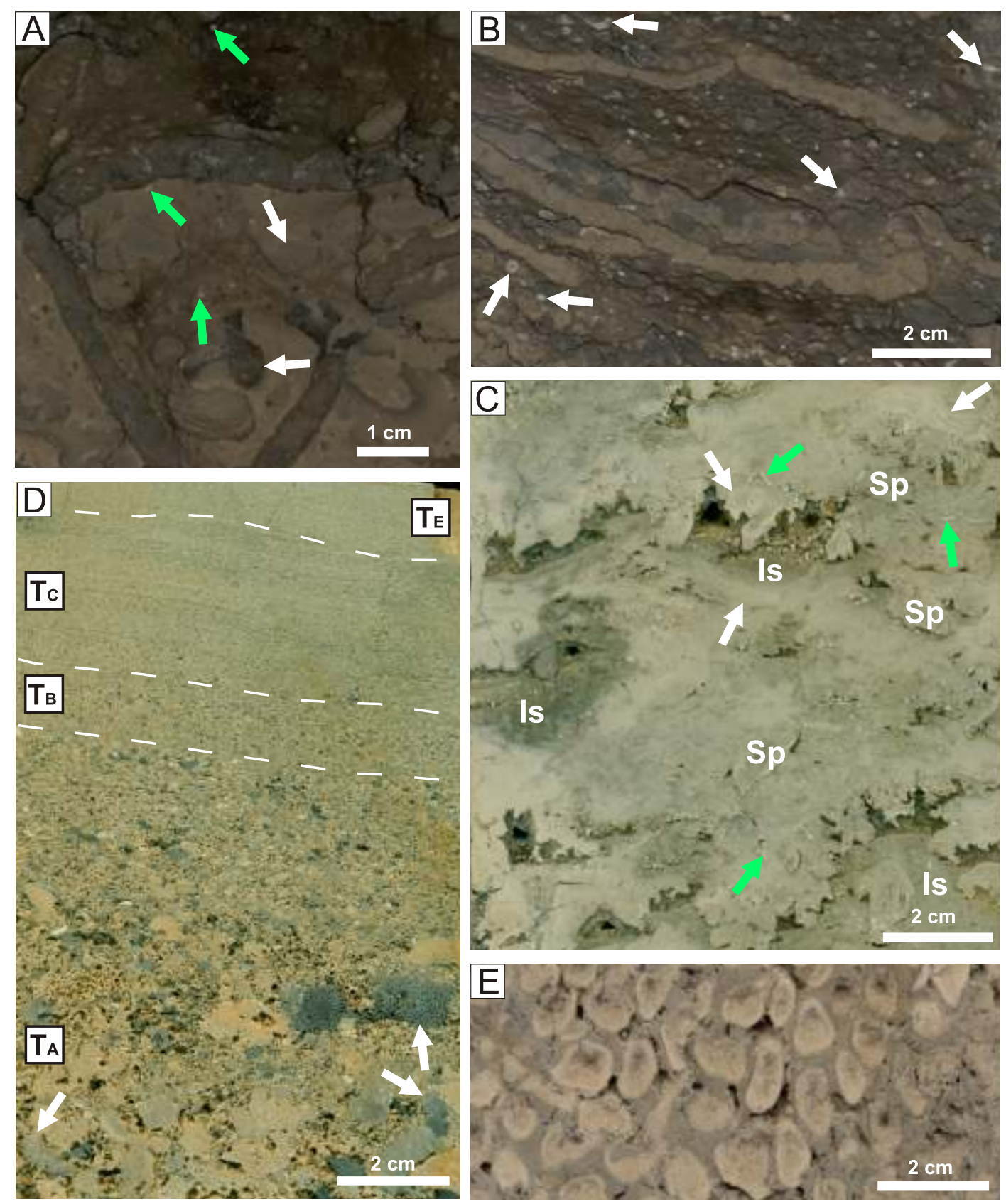

Fig. 6. Polished slabs from Upper Jurassic deposits from the study area

A, B - sponge marly limestones and marls ( $F 1)$ close to the boundary with Callovian deposits. A - numerous siliceous sponges within marly limestone with tuberoids (white arrows) and fragments of bryozoan (green arrows). In the upper part of photo, marl is visible. G93 borehole, depth $283.0 \mathrm{~m}$; B - horizontally oriented siliceous sponges within marl with numerous bryozoan (white arrows) and clay laminae. G82 borehole, depth $187.6 \mathrm{~m}$; C - microbial sponge limestones (F3). Numerous stromatactis-like cavities and stromatactoid cavities with digitated roofs filled partly or entirely with calcite cements in the upper parts, and with internal sediments (Is) in the bottom. Numerous Crescentiella (green arrows), siliceous sponges (Sp) and stromatolites (white arrows) are observed in the rock. B404 borehole, depth $72.5 \mathrm{~m}$; $\mathbf{D}$ - gravity flow deposits (F4) with the Bouma sequence $\mathrm{T}_{\mathrm{A}}-\mathrm{T}_{\mathrm{C}}, \mathrm{T}_{\mathrm{E}}$. Black and dark grey grains are fragments of sponges (some pointed by arrows). N43 borehole, depth $256.0 \mathrm{~m}$; E - coral bafflestone within coral and pelitic limestones (F7). F68P borehole, depth $223.8 \mathrm{~m}$

ment together with detritus of echinoderms, bivalves, bryozoans, oysters, serpulid worm tubes, gastropods, corals (up to $3 \mathrm{~cm}$ in size) and fine oncoids (type 2 oncoids, cf. Védrine et al.,
2007) (Figs. 7E and 8B). The Bacinella-type oncoids have sub-elliptical shapes with lobate contours (Fig. 8B).

Two types of Bacinella-type oncoids were identified (cf. Kutek and Radwański, 1965). The first includes oncoids with 

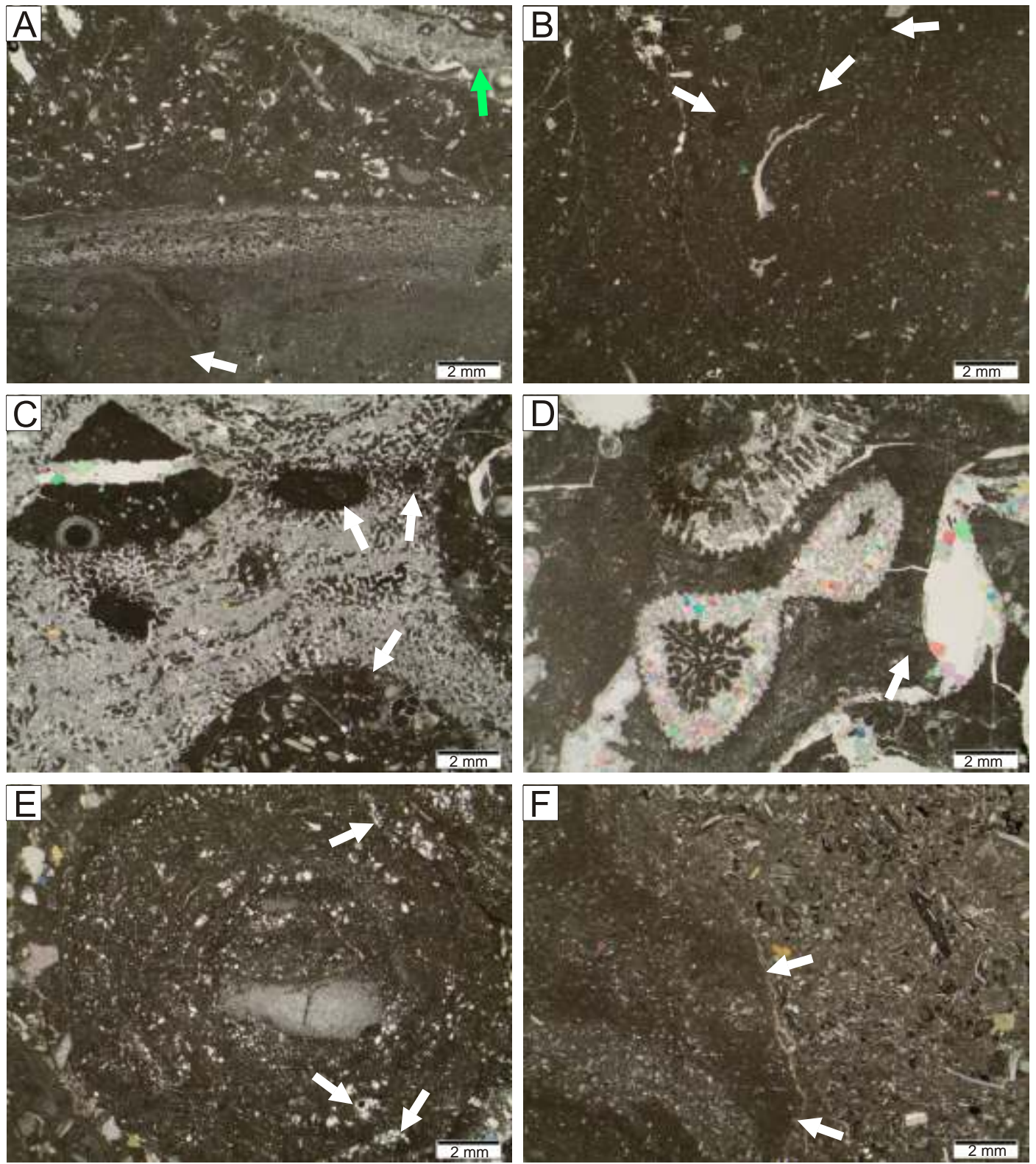

Fig. 7. Microfacies from Upper Jurassic deposits of the study area

A - laminated finger-shape thrombolite (white arrow) covered with agglutinated stromatolite. Above, stromatolite wackestone with bioclasts and a single coral (green arrow) is visible. Microbial-sponge limestones (F3). N71P borehole, depth $249.7 \mathrm{~m}$; B - wackestone with fragments of bivalves, echinoderms and Crescentiella (arrows). Fine-grained and pelitic limestones (F5). N71P borehole, depth $246.3 \mathrm{~m}$; C - coral framestone. Numerous borings, filled with mudstone and bioclastic wackestone (arrows), are present in the coral. Coral and pelitic limestones (F7). G110D borehole, depth $279.5 \mathrm{~m}$; D - coral bafflestone. Corals are partly or completely dissolved and recrystallized. Spaces between corals are filled with bioclastic mudstone-wackestone, locally with microbolitic laminae (arrow). N71P borehole, depth $219.0 \mathrm{~m}$; E - Bacinella-type oncoid. Central part of the oncoid is a fragment of echinoderm. Cortex is laminated with Bacinella irregularis and Troglotella incrustants (arrows). Bacinella-type oncoid limestones (F8). G108D borehole, depth $273.5 \mathrm{~m}$; F-marl clast with fine bioclasts and distinct contours (arrows) within marly-bioclastic packstone with single ooids. Clastic-bioclastic marly limestones (F10). G116D borehole, depth $283.2 \mathrm{~m}$

bioclast nuclei. Such forms are circular, oval or elongated, with wavy contours, dependent on bioclasts shapes, and distinct boundaries with the surrounding matrix. Typical components are Bacinella-type and micritic laminae forming cortex, which allows including them into the type 3 oncoids (e.g., Védrine et al., 2007; Bádenas and Aurell, 2010). The cortex is sometimes perforated by Troglotella incrustans (Fig. 7E) and bored by bi- valves. The second type resembles the type 4 oncoids (Védrine et al., 2007), as both are formed by the Bacinella-type meshwork with micrite and rare echinoderm fragments. Their boundaries with the bioclastic matrix are commonly diffuse.

The uppermost several centimetre thick interval of Bacinella-type oncoid limestones (F8) is more clayey and contains massive elliptical oncoids (up to $\sim 2 \mathrm{~cm}$ across). The upper 

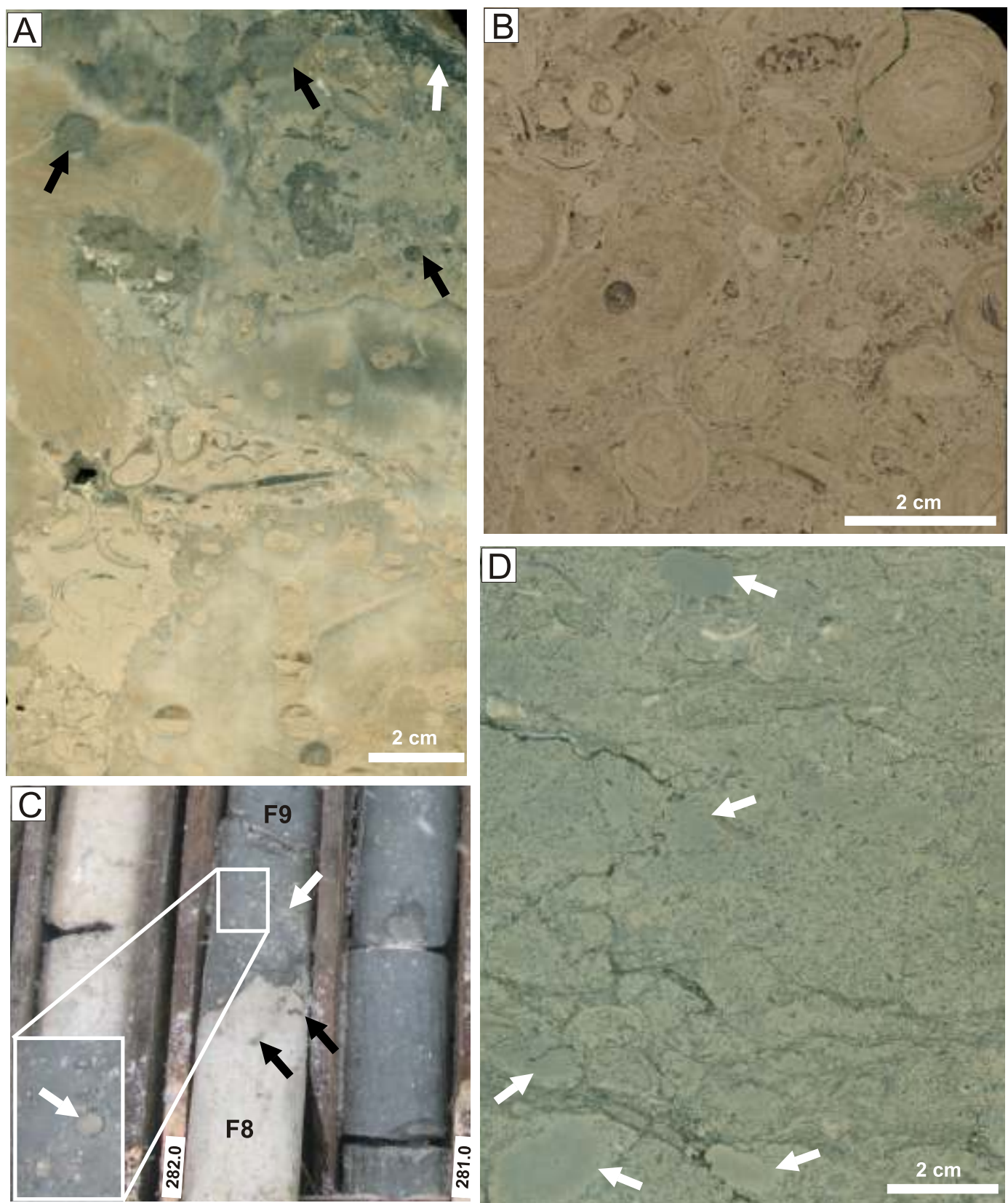

\section{Fig. 8. Polished slabs and photo of drill core from upper jurassic deposits of the study area}

A - coral and pelitic limestones (F7). Numerous corals with borings filled or partly filled with internal sediment, embedded within the matrix with bivalves and fragments of echinoderms. In the upper part of photo, borings are filled with marl (black arrows) and the matrix is more marly. The contact with overlying marls (F9) is visible (white arrow). G116D borehole, depth 291.5 m; B - Bacinella-type oncoid limestones (F8). Numerous oval and elliptical oncoids, some with borings, within fine-grained bioclastic matrix. G110D borehole, depth $279.8 \mathrm{~m}$; C - uneven contact along a hardground between Bacinella-type oncoid limestones (F8) and marls (F9). In limestone, marl-filled borings are visible (black arrows). In the lower part of marl, numerous oncoids are present (white arrows), which disappear upward. G121D borehole, depth $281.8 \mathrm{~m}$; D - clastic-bioclastic marly limestones (F10). Marl clasts (arrows) surrounded by marly bioclastic matrix with pyritized ooids. Clasts are in general devoid of ooids and bioclasts. G116D borehole, depth $281.6 \mathrm{~m}$

boundary with the overlying marls (F9) is sharp and uneven, commonly with a hardground (Fig. 8C).

Facies interpretation: this facies type can be characterized by moderate-energy conditions in the inner-ramp environment (Védrine et al., 2007; Bádenas and Aurell, 2010). The Bacinella-type oncoids are common in the inner-ramp, lagoonal, back-reef and backshoal, shallow depositional environment of low accumulation rate, having clear, normal-marine wa- ters (Kutek and Radwański, 1965; Leinfelder et al., 1993; Dupraz and Strasser, 1999; Védrine et al., 2007; Bádenas and Aurell, 2010). Oval Bacinella-type oncoids in facies F8 suggest moderate- to high-energy water conditions. Such oncoids are known from the mid-high energy oolitic facies of the neighbouring areas (Kutek and Radwański, 1965; Krajewski et al., 2016; see also F11). 
MARLS (F9)

The F9 facies attains $13 \mathrm{~m}$ in thickness and is separated from the F8 facies by an uneven erosional surface (Figs. 2, 3, 5 and $8 \mathrm{C})$. The lowermost ( $0.7 \mathrm{~m}$ thick) part of succession F9 comprises marls with numerous crinoids (see Krajewski et al., 2019) and common nonporous elliptical oncoids (up to $1.5 \mathrm{~cm}$ across; Fig. 8C). Up the sequence, mass occurrence of thin- or thick-canal burrows of diffused boundaries is noticed. The boundary between facies F9 and the overlying F10 facies is erosional with many bored hardground clasts.

Facies interpretation: the F9 marls are deep-water facies deposited in an outer-ramp setting and represent carbonate ramp inundation. The sedimentary environment of hardground clasts with many generations of borings, encountered in the top part of succession F9, has already been studied in the Holy Cross Mountains by Gruszczyński (1986) and Krajewski et al. (2014, 2017). The composition of the borings may indicate that colonization and recolonization of the clasts took place in a shallow-water environment.

\section{CLASTIC-BIOCLASTIC MARLY LIMESTONES (F10)}

The F10 facies is up to $~ 3.5 \mathrm{~m}$ thick (Figs. 2, 3, 5 and Table 1) and comprises clasts of marls and marly limestones (up to 8 $\mathrm{cm}$ in size) (Fig. 7F), embedded in marly matrix composed of packstones/grainstones with mass occurrence of bivalve shells, fragments of echinoderms, common pyritized ooids, and gastropods (Fig. 8D). Frequent are irregular, marly-bioclastic laminae (up to a few centimetres thick). The amount of clasts decreases in the upper part of the succession where grey marly limestones occur with numerous oncoids (up to $\sim 2 \mathrm{~mm}$ across) growing onto the fragments of bivalve, echinoderm and gastropod shells, and pyritized ooids. The contact of facies F10 with the oolitic limestones (F11) is sharp and commonly marked by a bored hardground encrusted by numerous bivalves (up to a few centimetres in size), fine ooids and oncoids.

Facies interpretation: the clastic-bioclastic marly limestones are the transitional facies between the outer ramp (F9) and the inner ramp, foreshoal to shoal (F11) facies.

\section{OOLITIC LIMESTONES (F11)}

The thickness of $F 11$ facies succession reaches up to $36 \mathrm{~m}$ (Figs. 2, 3, 5 and Table 1). It starts with oolitic-oncolitic, biodetrital limestones with rare grey bored hardground clasts, several centimetres in diameter (although large fragments are less common). These clasts disappear $\sim 1 \mathrm{~m}$ above the bottom surface of the succession. The sediment contains ooids of rounded or slightly elliptical shapes (up to $1.2 \mathrm{~mm}$ in size). Aggregate grains (up to $3 \mathrm{~mm}$ across), which are formed by ooids, as well as skeletal grains, bivalve shells, coral detritus, echinoderm plates, and serpulids are abundant. There are also numerous bivalve-bored hardgrounds with oolitic clasts and aggregate grains, in which the ooids are cemented by grey calcisparite (Fig. 9A, B). In the middle and upper parts of succession F11, ooids are accompanied by corals detritus, numerous bioclasts (mostly thick-shelled bivalves and echinoderms) and oval Bacinella-type oncoids (up to $3 \mathrm{~cm}$ in diameter) (Fig. 9C). The top part of succession $\mathrm{F} 11$ is a hardground with numerous borings (Fig. 10B).
Facies interpretation: the F11 facies represents the inner ramp with shoal, backshoal and lagoonal environments (e.g., Flügel, 2004). The lower part of F11 was deposited in the inner-ramp high-energy oolitic shoal environment. The high-energy conditions are indicated by the bored hardground clasts and the oolitic clasts (Fig. 10A). The middle and upper parts of the succession represent inner-ramp, backshoal to lagoonal, moderate-energy conditions confirmed by the presence of oval Bacinella-type oncoids (Kutek and Radwański, 1965; Védrine et al., 2007; Bádenas and Aurell, 2010) and by coral detritus.

\section{ONCOLITIC LIMESTONES (F12)}

The oncolitic limestones, up to $\sim 7.5 \mathrm{~m}$ in thickness, are dominated by oncoids (3-8 mm in size) (Figs. 2, 3, 5 and Table 1) corresponding to types 1 and 2 after Védrine et al. (2007). Oncoids are accompanied by very abundant echinoderm fragments and bivalves (Fig. 9D), as well as by clasts (up to $\sim 3 \mathrm{~cm}$ across) and single ooids gradually disappearing up the sequence. The oncoid nuclei are mostly echinoderm and bivalve fragments (Fig. 9E). The upper boundary of succession F12 with the overlying F13 marls is sharp, with common clasts reaching several centimetres in diameter.

Facies interpretation: facies F12 formed in an open-marine, inner-ramp depositional environment with high-energy episodes (cf. Kutek and Radwański, 1965, 1967; Flügel, 2004; Védrine et al., 2007).

\section{MARLS (F13)}

This succession attains a thickness of $\sim 7.5 \mathrm{~m}$ and begins with a marl layer ( $0.1-0.5 \mathrm{~m}$ thick) containing numerous crinoids (Krajewski et al., 2019), echinoderms and, locally, angular clasts of F12 facies sediments (Figs. 2, 3, 5 and Table 1). The amount of clasts decreases up the sequence within the interval ranging in thickness from several to a few tens of centimetres. Above, a biodetrital limestone layer appears ( $0.5 \mathrm{~m}$ thick), having sharp bottom and top surfaces. It is overlain by a homogeneous thin-bedded marl layer with rare burrows (Fig. 9F) and some hardgrounds in its upper part. The top surface is a hardground or marl containing hardground clasts.

Facies interpretation: the sedimentary succession of F13 marls and lack of shallow-water fauna and microfauna is interpreted as inundation and outer-ramp environment.

\section{SPONGE-BIVALVE-ONCOLITIC LIMESTONES AND MARLY LIMESTONES (F14)}

The F14 facies succession is up to $75 \mathrm{~m}$ thick (Figs. 2-5 and Table 1). Its deposition started with biodetrital limestones containing bivalve shells, fragments of echinoderms, siliceous sponges, crinoids (Krajewski et al., 2019) and irregular or rounded oncoids growing onto the bioclasts (Fig. 5). Within the several metre thick interval, the limestones grade into marly limestones (several tens of metres thick) commonly intercalated by marl layers (up to a few tens of centimetres thick). Both the marly limestones and marls are full of fragments of various species of siliceous sponges of both rounded and jagged shapes (originally tube-, dish- and bowl-shaped; cf. Trammer, 1982, 1989; Olóriz et al., 2003). Transversal cross-sections of 

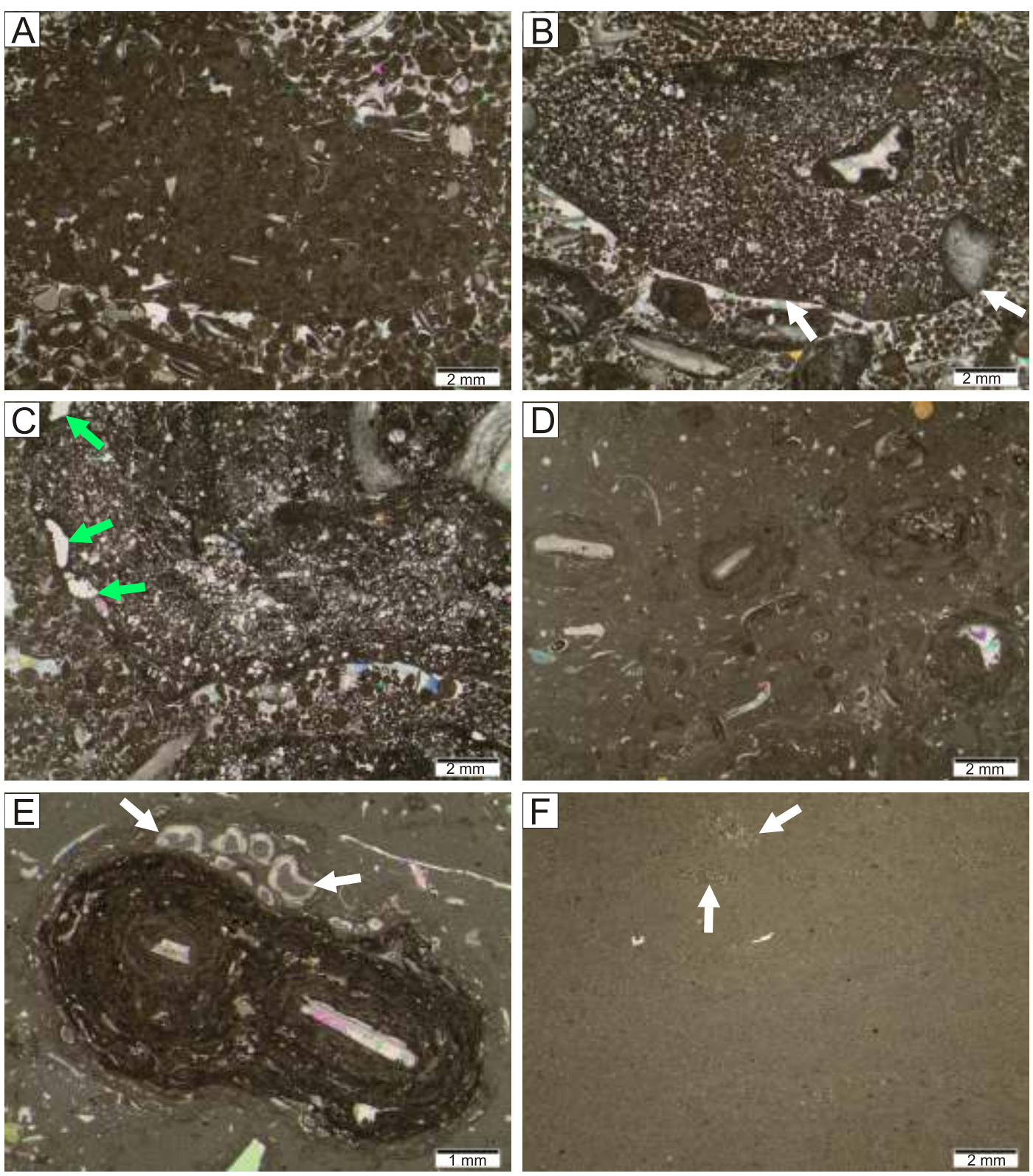

Fig. 9. Microfacies from Upper Jurassic deposits of the study area

A- oolitic grainstone with an oolitic clast with sharp boundaries. The clast is composed of ooids and bioclasts surrounded by calcite micrite and partly by calcite cements. Oolitic limestones (F11). G116D borehole, depth 270.0 $\mathrm{m}$; B - oolitic grainstone with an oolitic clast with sharp boundaries (white arrows). Bioclasts and ooids forming the clast are cut at the clast boundary. Oolitic limestones (F11). G116D borehole, depth $262.5 \mathrm{~m}$; C Bacinella-type oncoid within oolitic grainstone. Numerous Entobia sp. with alveoli are present (arrows). Cortex of the oncoid is composed mainly of Bacinella and micritic laminae. Oolitic limestones (F11). G116D borehole, depth $265.0 \mathrm{~m}$; D - oncoid floatstone embedded in matrix with fragments of echinoderms, bivalves and bryozoans. Oncolitic limestones (F12). N71P borehole, depth $153.2 \mathrm{~m}$; E - oncoid floatstone. Most of cortex consists of microbial laminae and bioclasts. The outermost part of cortex is composed of calcite micrite, microbial laminae and fine bioclasts, incrusted by serpulids (arrows). Oncolitic limestones (F12). N71P borehole, depth $150.6 \mathrm{~m} ; \mathbf{F}-$ marl with fine bioclasts and single burrows (arrows). Marls (F13). N71 borehole, depth $148.7 \mathrm{~m}$

tube-shaped sponges reveal their sizes up to $3 \mathrm{~cm}$. There are also bivalve and echinoderm fragments and limestone clasts (Figs. 10C, D and 13A, B). In this part of F14, oncoids growing onto the bioclasts are observed, but their quantity in comparison with the lower part of F14 is lower. The clasts are usually up to several centimetres in size, although larger specimens were observed as well. The clasts are easily discernible due to beige colour contrasting the grey matrix full of bioclasts. The clasts are composed of biodetrital limestone with common fragments of echinoderms, bivalves and siliceous sponges. Occassionally, limestone layers are observed (several to tens of centimetres thick) with common in situ sponges, echinoderm and bivalve fragments, and rare clasts (up to several centimetres across). In its upper part ( 10-15 m thick), the F14 facies shows mass occurrence of biodetrital limestone fragments with dispersed sponges embedded within marly-bioclastic matrix. In 
some drill cores, this part of succession F14 is represented by a limestone with shell biodetritus, fragments of echinoderms, rare siliceous sponges and only single intercalations of marl with clasts (a few centimetres in thickness). Ammonites are also common. The transition to the overlying F15 facies is visible over the interval of several centimetres. Locally, a hardground and/or hardground clasts occur in the top part of succession F14.

Facies interpretation: the F14 facies sediments are biostromes composed of eroded and redeposited siliceous sponges. According to Leinfelder et al. (1994, 1996), siliceous sponges and breccia layers are frequent in a mid-ramp setting. Both the marly limestones and the marls with numerous sponge debris and clasts represent either parabiostromes, in which $>80 \%$ of sponges have been destroyed, or allobiostrome, in which $0 \%$ of sponges are in place of growth (cf. Kershaw, 1994). However, more calcareous parts of succession F14 may represent autoparabiostromes, in which $>60 \%$ of sponges are in place of growth (cf. Kershaw, 1994).

\section{MARLS AND MARLY LIMESTONES (F15)}

The F15 facies reaches a thickness of up to $\sim 35 \mathrm{~m}$ (Figs. 2-4). It comprises grey thin-bedded marls with minor marly limestones, commonly burrowed and containing rare bioclasts. The lower part of succession F15 is dominated by marls. In the bottom layer ( $\sim 3 \mathrm{~m}$ thick), numerous fragments of crinoids (Krajewski et al., 2019) and echinoderms are observed, accompanied by clasts of marly limestones and marls (Fig. 11A). Both the middle and upper parts of succession F15 have more intercalations of marly limestones (up to $30 \mathrm{~cm}$ thick) showing diffuse boundaries and hardgrounds. The top surface of succession F15 is sharp and rough, with a hardground and burrows filled with the overlying F16 facies sediment (Figs. 5 and Table 1). Marl clasts (up to several centimetres in size) are also common.

Facies interpretation: the F15 facies is interpreted as deposited in an outer ramp inundated during the transgressive-regressive cycle. The lower part of succession F15 represents the onset of transgression. The disappearance of bioclasts and clasts upward the sequence and the deposition of marls are related to a sea level highstand. Both the middle and upper parts of succession F15 containing numerous marly limestone intercalations and hardgrounds indicate a shallowing trend from outer- to inner-ramp environments represented by facies $\mathrm{F} 16$.

\section{ONCOLITIC LIMESTONES (F16)}

The oncolitic limestones (up to $6 \mathrm{~m}$ thick) (Figs. 2-4 and Table 1) reveal good sorting of ellipsoidal oncoids (up to $\sim 2 \mathrm{~cm}$ in size) (Fig. 11C). These oncoids are commonly bored and grow over the fragments of bivalve shells, less commonly over echinoderm and gastropod shell fragments. The oncoids are embedded within the matrix (commonly marly) full of shelly biodetritus and clasts of biodetrital limestone. The oncolitic limestones are often intercalated with marl layers (up to $0.3 \mathrm{~m}$ thick) showing sharp top and bottom surfaces, and containing abundant ellipsoidal oncoids. The sorting of oncoids is better in the marls than in the limestones. In the bottom part of succession F16, the typical feature is the presence of hardgrounds or hardground clasts (Fig. 11B). Transition from facies F16 to the overlying $\mathrm{F} 17$ limestones and marls is gradual and marked by a decreasing amount of oncoids.
Facies interpretation: the hardground in the bottom part of succession F16 separates the outer ramp (F15) from the inner ramp (F16) facies. Deposition of facies F16 took place in shallower areas of the open-marine, inner-ramp setting.

\section{MARLY LIMESTONES AND MARLS (F17)}

The F17 facies comprises thin- to medium-bedded marly limestones and marls (up to $36 \mathrm{~m}$ thick) (Figs. 2-5 and Table 1). Three lithological varieties can be observed in the succession:

- lowermost part composed of limestone and marly limestone (up to several metres thick) with sponge spicules, Crescentiella, serpulids, crinoids, bivalves, echinoderms, foraminifers and Saccocoma intercalated with marl with crinoids, oncoids and bivalves (Fig. 13C),

- middle part represented by marl (up to several metres thick) with burrows, and

- upper part (some metres thick) represented by marl with upward-increasing proportion of marly limestone intercalations with hardgrounds (Fig. 5).

The upper boundary of facies F17, with gastropod limestones, marly limestones and marls of facies F18, is diffused; however, in some boreholes, a hardground and hardground clasts were observed.

Facies interpretation: the $\mathrm{F} 17$ facies represents a transgressive-regressive cycle. The lower part with sponge spicules, crinoids, oncoids and bivalves was deposited during transgression (cf. Flügel, 2004). The middle part is represented by marls with burrows, deposited during a sea level highstand. The upper part with clasts and hardgrounds indicates a shallowing trend from an outer- to inner-ramp environment of the following facies F18.

\section{GASTROPOD LIMESTONES, MARLY LIMESTONES AND MARLS (F18)}

The F18 facies (up to $31 \mathrm{~m}$ thick) comprises medium-bedded, ligh grey, biodetrital limestones interbedded by mediumor thin-bedded marly limestones and/or marls. The biodetrital limestones are dominated by gastropods (up to $\sim 4 \mathrm{~mm}$ in size) accompanied by bivalve shells, echinoderm fragments and rare oysters. The biodetritus forms laminae or layers inclined up to $3^{\circ}$ (from a few millimetres to several centimetres thick) of distinct, straight or undulating surfaces (Fig. 12A). There are common lenses of biodetritus (several centimetres long and up to several millimeters thick) and sets of alternating laminae or layers of biodetritus (from several to a few tens of centimetres thick) and laminae or layers of marly limestone with dispersed biodetritus and single quartz grains (from several millimetres to several centimetres thick). The typical feature of facies F18 is vertical downward-narrowing fractures $(-2 \mathrm{~cm}$ long and up to $\sim 0.5 \mathrm{~cm}$ wide) filled with calcite cement, which locally contain fine, angular clasts (Figs. 12A and 13E).

Facies interpretation: deposition of facies F18 presumably took place on an extremely shallow-water carbonate mudflat, whose sedimentary environment corresponded to intertidal and shallow subtidal zones within the inner-ramp setting. The sedimentary structures (e.g., mudcracks) and vadose (with calcareous clasts) and phreatic cements indicate very shallow-water conditions with local temporary emergences (e.g., Flügel, 2004). The sedimentation generally occurred in shallow waters, at a depth changing probably within only a several-metre interval. The sea bottom was slightly inclined, with small relief varia- 

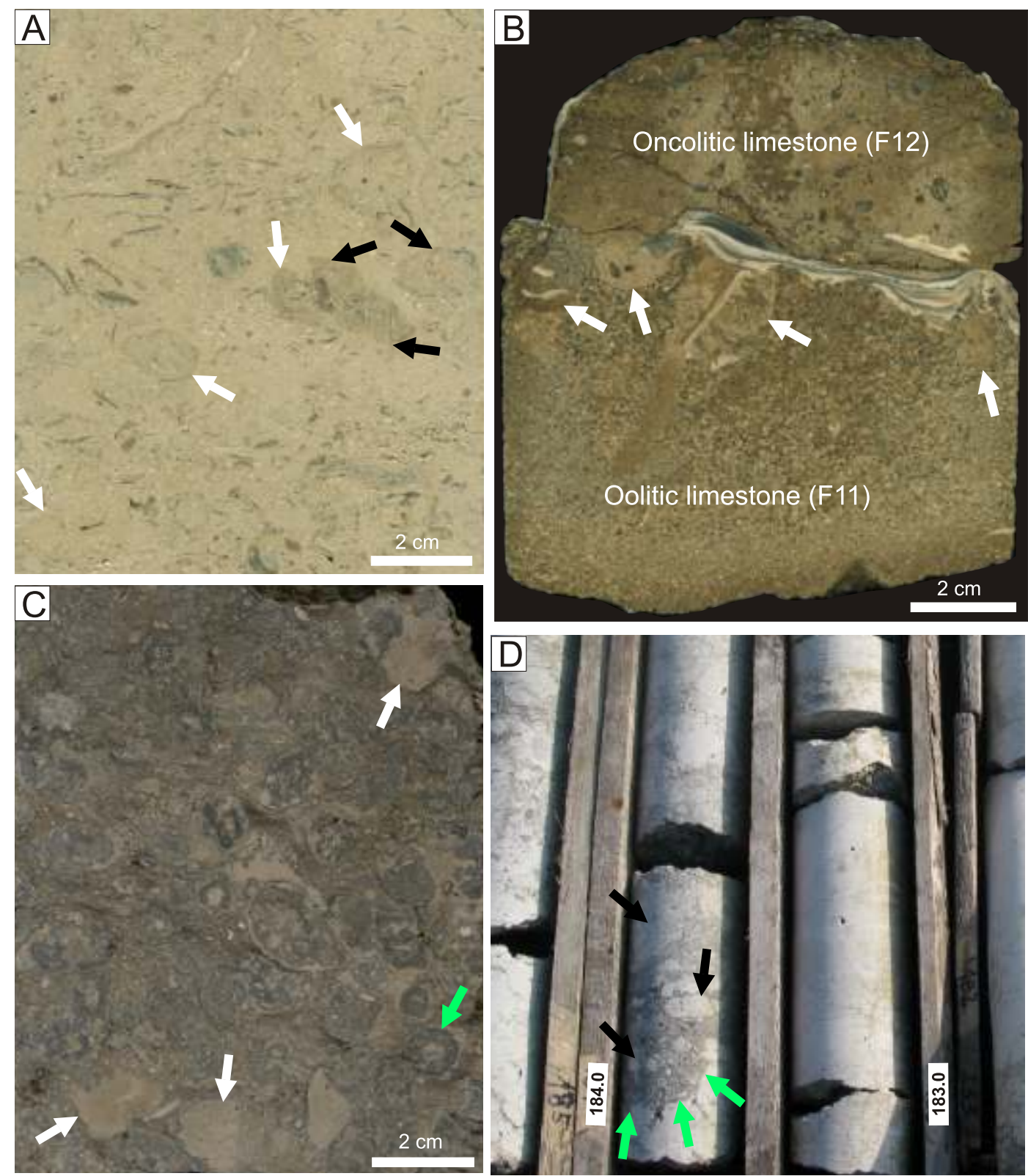

Fig. 10. Polished slabs and photo of drill core from Upper Jurassic deposits of the study area

A - oolitic limestones (F11) with numerous bivalves and dark beige oolitic clasts (white arrows). Boundaries between clasts and oolitic matrix are sharp. Bivalve shells within clasts do not continue within the matrix (black arrows). G116D borehole, depth $262.5 \mathrm{~m}$; B - contact of oolitic limestones (F11) with oncolitic limestones (F12). The boundary is a hardground with numerous borings (arrows) and bivalve incrustation. N71P borehole, depth $159.0 \mathrm{~m}$; C - sponge-bivalve-oncolitic limestones and marly limestones (F14). Numerous sponges with borings and limestone clasts (white arrow) within marly-bioclastic matrix containing bivalves and fragments of echinoderms. The clasts contain sponges and bivalves, but are not marly. Cross-section of a sponge is visible (green arrow). B209 borehole, depth $170.0 \mathrm{~m}$; D - errosional channel with listric shape contours (green arrows) within sponge-bivalve-oncolitic limestones and marly limestones (F14). The channel is filled with marl containing chaotically floating limestone clasts (black arrows). G115D borehole, depth $184.8 \mathrm{~m}$

tions, as demonstrated by dip angles of biodetritus laminae and layers below $3^{\circ}$. The proximity of land is indicated by quartz grains supplied by waters from the continent. A similar facies development is observed in an Upper Jurassic peri-shore lagoonal enviroment of western Ukraine in the Carpathian Foredeep basement (Krajewski et al., 2011b).

\section{MARLS, MARLY LIMESTONES AND SILTS (F19)}

The F19 facies attains a thickness of up to $27 \mathrm{~m}$ (Figs. 4, 5 and Table 1). These are mostly grey marls (up to $\sim 4 \mathrm{~m}$ thick) showing thin bedding and flat or slightly inclined interbedding planes. The marls are intercalated by thin- and medium-bedded, pelitic and biodetrital marly limestones. Less common are 

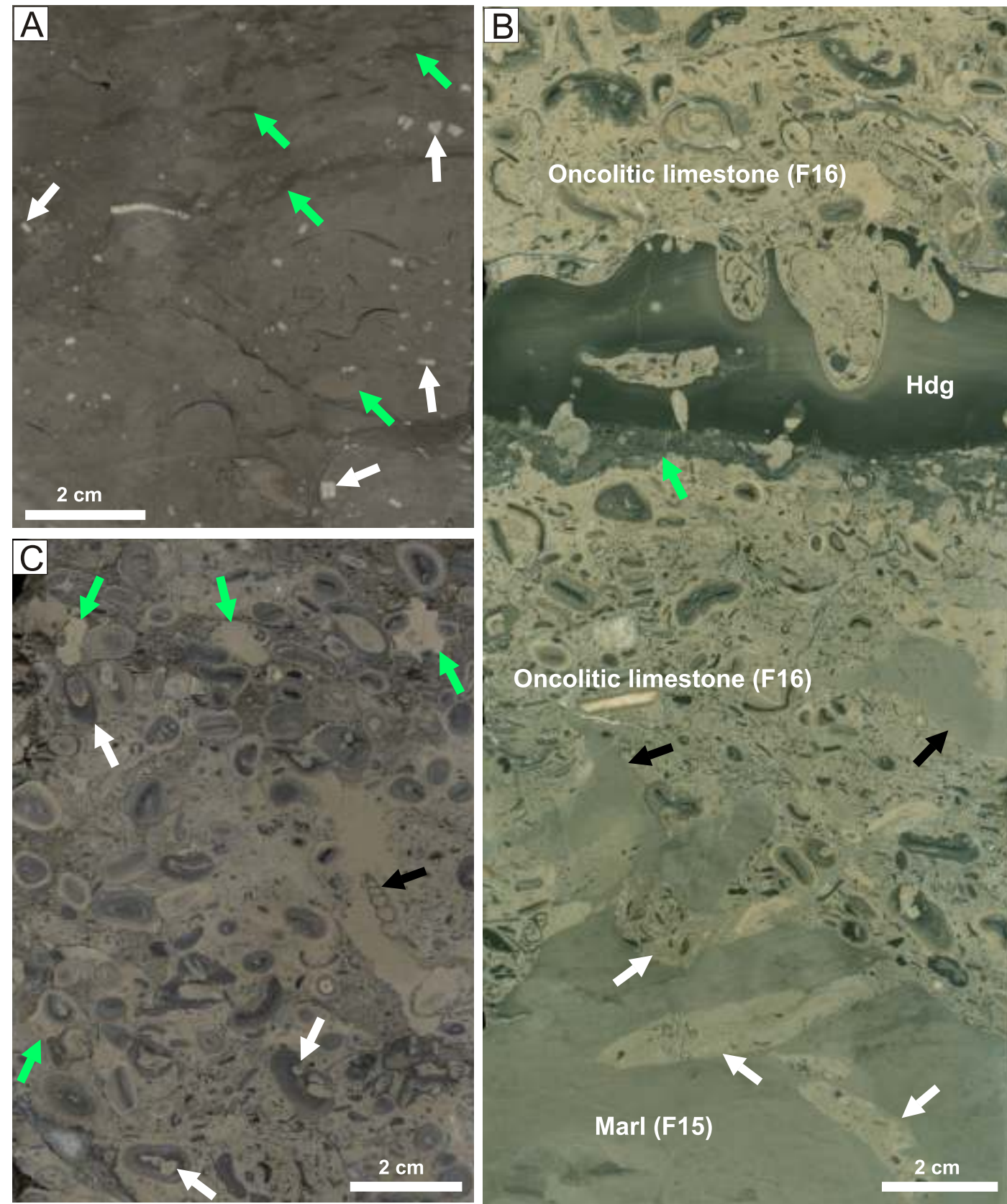

Fig. 11. Polished slabs from Upper Jurassic deposits of the study area

A - lowermost part of marls and marly limestones (F15). Marl with numerous crinoids (white arrows), burrows (green arrows) and brachiopods. G108D borehole, depth $159.4 \mathrm{~m}$; B - lowermost part of oncolitic limestones (F16) with a hardground (Hdg). In the lower part of photo, contact with marls and marly limestones (F15) is visible. Marls contains numerous borings (white arrows). Oncolitic limestones contain elliptical and elongated oncoids, angular marl clasts (black arrows), bivalves and fragments of echinoderms. Hardground is laminated and shows borings. Its lower boundary is incrusted by microbialites (green arrow). G120D borehole, depth 141.6 $\mathrm{m} ; \mathbf{C}$ - oncolitic limestones of F16 containing numerous oval oncoids with borings (white arrows). In the upper part of photo and partly in its middle part, the matrix is marly and contains fragments of echinoderms and limestone angular clasts with oncoids (green arrows). Single gastropod (black arrow). B213 borehole, depth $124.0 \mathrm{~m}$

greenish-grey silts interbedded by biodetrital marly limestones. Marl/marly limestone interfaces are usually sharp. There are frequent marl beds (up to $\sim 0.8 \mathrm{~m}$ thick) full of clasts of pelitic and biodetrital marly limestones. The clasts are rounded or angular, ranging in size from a few to several centimetres; however, some specimens can be larger than the $10 \mathrm{~cm}$ drill core diame- ter. The bottom surfaces of marl beds are sharp and irregular, commonly listric. Burrows are often observed in both the marls and marly limestones. The biodetrital marly limestones and marls contain frequent wavy, connected streaks of marl (up to $\sim 4 \mathrm{~cm}$ thick). Apart from bivalve shells (up to $3 \mathrm{~cm}$ in size), the biodetrital marly limestones host oncoids overgrowing the shell 
biodetritus. Silts attain several metres thick with common flat and platy fissility, and are intercalated by biodetrital marly limestones (up to $0.5 \mathrm{~m}$ thick). The silts contain biodetrital marly limestone clasts and numerous but dispersed gypsum crystals $(<0.5 \mathrm{~mm}$ in size $)$.

Facies interpretation: the F19 facies was presumably deposited in a tidal flat zone. Dispersed fine gypsum crystals point to interstitial crystallization from pore solutions, which, in turn, indicates increased salinity of pore solutions during the sedimentation, caused by, e.g. evaporation. Deposition of facies F19 took place over a flat area, as suggested by generally flat or slightly (a few degrees) dipping interbedding planes of marly limestones and marls, and by platy fissility of marls and silts. Locally, the basin floor revealed depressions of relatively steep listric slopes. Some of them might have been the channels in which marls and marly limestone clasts were laid down. Generally, the clasts are lithologically rather monotonous, whereas their angular shapes indicate transport from proximal source areas.

\section{MARLS AND MARLY LIMESTONES WITH NANOGYRA ACCUMULATIONS (F20)}

The sediments of facies F20 are up to $72 \mathrm{~m}$ thick (Figs. 4, 5 and Table 1). These are mostly marls (up to $4 \mathrm{~m}$ thick) intercalated with medium- and thin-bedded pelitic and biodetrital limestones. In the lowermost part of succession F20, a marl layer is observed ( $4.5 \mathrm{~m}$ thick) with mass accumulations of Nanogyra oysters and numerous limestone clasts (Fig. 12B). It is interbedded by layers of biodetrital limestone containing abundant oysters. The top and bottom boundaries of facies F20 are sharp and commonly marked by accumulations of calcareous clasts (Fig. 4). In the marl, the Nanogyra oysters are densely packed. Their shells are chaotically oriented and show partial fragmentation, although complete shells were observed as well. Typical components of the marl layers are limestone clasts (up to several centimetres in size) of rounded or angular shapes. These clasts contain numerous oyster shells being often not in contact with each other. Up the sequence, marls are observed (several tens of metres thick) interbedded with pelitic and biodetrital marly limestones (Fig. 4). The marls/marly limestones interbedding planes are usually sharp. The marls contain numerous layers (from 0.1 to $0.6 \mathrm{~m}$ thick) full of fragmented Nanogyra shells and abundant limestone clasts. These layers disappear in the upper part of facies succession F20. There are also common layers (up to a few tens of centimetres, rarely up to $\sim 3 \mathrm{~m}$ ) with numerous clasts of marly, pelitic and biodetrital marly limestones. Their shapes are rounded or angular and their size varies from a few to several centimetres; however, some specimens exceed the drill cores diameters. Bottom surfaces of such layers are sharp and irregular. The biodetrital marly limestones contain bivalves shells (up to $3 \mathrm{~cm}$ in size), dispersed oyster shells (up to $10 \mathrm{~cm}$ long), and oncoids growing on shell biodetritus. In both the marls and marly limestones, burrows are visible.

Facies interpretation: the deposition of facies F20 presumably took place on a tidal flat, under low-energy hydrodynamic conditions of a muddy coast (cf. Wang et al., 2002). This generally flat sedimentary evironment had numerous, commonly meandering channel-like depressions, which drained the water flowing from adjacent elevations (cf. Wang et al., 2002). These channels transported not only the clay suspension but also the limestones clasts, which advocates temporal higher- -energy episodes. The presence of clasts eroded out from either the bedrock or the channel walls indicates that the currents might have had velocities high enough to erode and carry the clasts of diameters exceeding several centimetres. Mass accumulations of oyster shells forming layers up to $10 \mathrm{~m}$ thick are typical of Upper Jurassic sediments from the Mesozoic rim of the Holy Cross Mts. (Machalski, 1998; Zatoń and Machalski, 2013). These deposits belong to the Kimmeridgian Coquina Formation (Kutek, 1994) and contain Actinostreon gregareum, Deltoideum delta and Nanogyra virgula specimens. The former two oyster species settled both the rocky and soft muddy bedrock (Seilacher, 1984) under high-energy conditions. Hovewer, the reconstruction of sedimentary environment of coquinas with Nanogyra virgula is controversial. The accumulations of Nanogyra shells (up to $10 \mathrm{~cm}$ thick) are known from Kimmeridgian strata of northern and western France, and are interpreted as storm deposits (Fürsich and Oschmann, 1986). In the Mesozoic rim of the Holy Cross Mts., the sediments were described (up to $1 \mathrm{~m}$ thick) as containing chaotically oriented Nanogyra shells (Machalski, 1998). It seems that Nanogyra shell accumulations observed in facies F20 also reflect deposition in a high-energy environment, as indicated by chaotic orientation of the shells, their fragmentation, and the presence of limestone clasts with oyster shells. It can be hypothesized that the oyster shells and clasts were eroded off the bedrock and transported by the water currents to laterally extending sea-floor depressions of depths not exceeding several metres, or they were deposited directly in the channels when current velocities decreased.

\section{CLAYS, PALAEOSOLS (F21)}

This facies attains thicknesses from some centimetres to $1.5 \mathrm{~m}$ (Figs. 4, 5 and Table 1). The dominant rocks are black or dark grey clays of platy fissility, devoid of limestone clasts. Locally, palaeosols are observed (up to $0.1 \mathrm{~m}$ thick). Their top and bottom surfaces are sharp and regular or irregular. In the palaeosols, breccias with pedogenic structures are observed (Fig. 12C). The irregular angular clay clasts reach $1 \mathrm{~cm}$ in diameter, but some clasts can be elongated up to $\sim 2 \mathrm{~cm}$. The clasts are embedded within the clay matrix in which ferruginous stains, pore spaces, clay laminae, dispersed gypsum crystals (Fig. 13F) and rounded quartz grains are observed. The ferruginous stains form irregular, discontinuous streaks or nodules (up to $\sim 0.5 \mathrm{~cm}$ across), whereas the pore spaces observed in transversal sections are oval or lensoidal. Locally, wavy clay laminae (up to $0.5 \mathrm{~cm}$ thick) occur in the clay matrix.

Facies interpretation: the palaeosols of facies F21 can be compared to vertisols that develop over the bedrock enriched in clay matter in a climate having seasonal changes (Retallack, 2001). Vertisols host wedge-like cracks that are periodically open, slickenside surfaces resulting from shearing movements within the soil layer, and typical nodular structures (van Breemen and Buurman, 1998), and are covered with vegetation (e.g., Somasundaram et al., 2014). The sedimentological features of facies F21 point to their formation in a slightly shallower lower-energy and more uniform depositional environment than facies F20. The low-energy environment is evidenced by dominance of clay matter. The clasts present in vertisols were formed by in situ brecciation, as indicated by the lack of rounding and the absence of accompanying clasts originating from the older sediments. Moreover, root canals, and ferruginous stains in the matrix suggest that some shallow parts of the basin were emerged and vegetated. The presence of iron-rich hori- 

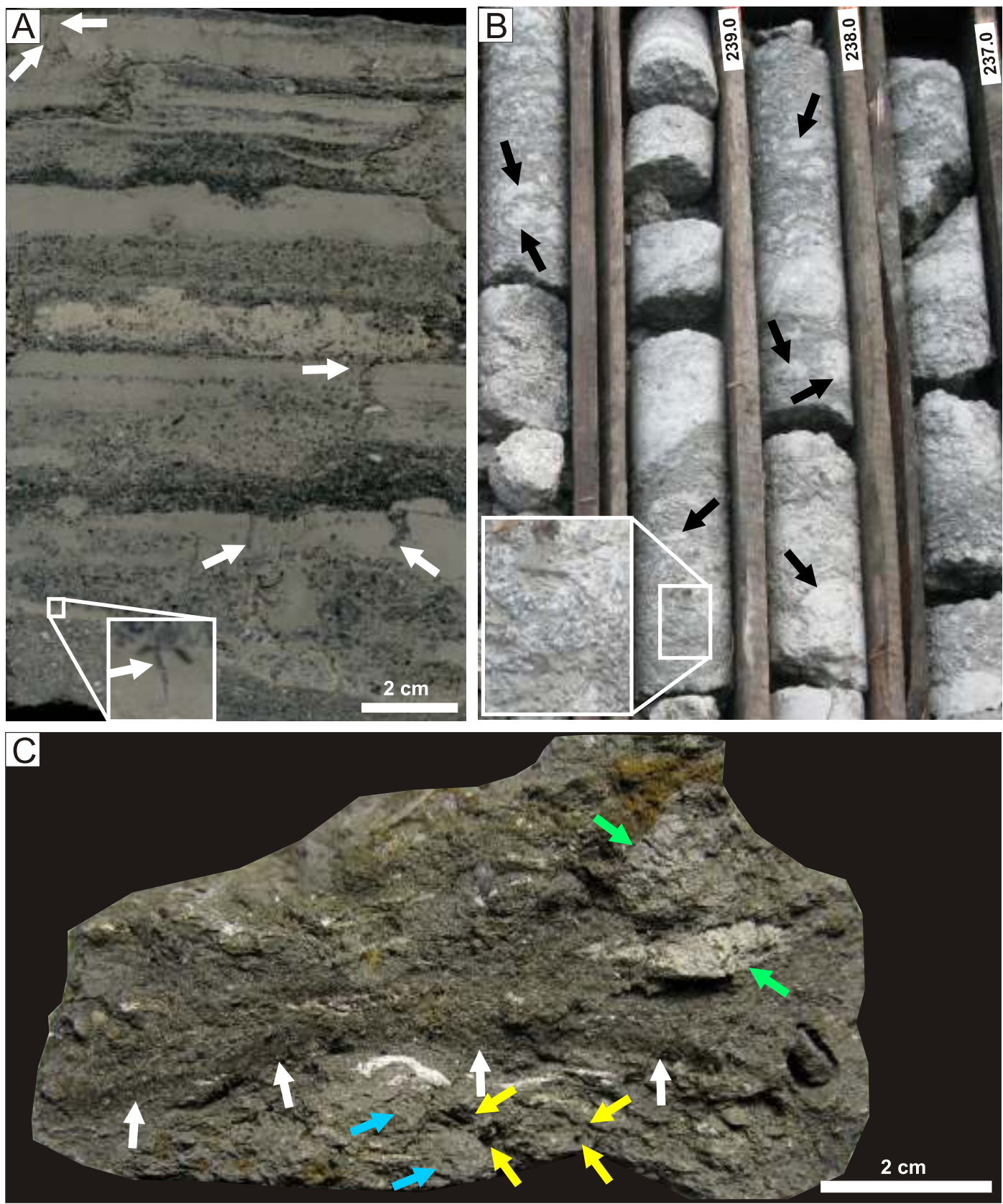

Fig. 12. Polished slabs and photos of drill cores from Upper Jurassic deposits of the study area

A - gastropod limestones, marly limestones and marls (F18). Marly limestones with mass occurrence of gastropods and bioclasts (bivalves and fragments of echinoderms) forming laminae with wavy contours. Gastropods in the marly limestone laminae are dispersed or form lenses or discontinuous laminae. In the marly limestone laminae, wedge-shaped cracks filled with calcite cements or gastropods are present (white arrows). G116D borehole, depth 96.0 m; B - marls and marly limestones with Nanogyra accumulations (F20). Marls with mass occurrence of Nanogyra shells and numerous limestone clasts with Nanogyra (black arrows). A88D borehole, depth 237.0-240.0 m; C - clays, palaeosols (F21). Palaeosol showing brecciated texture and numerous ferrigenous spots with diffuse contours. In the middle part of photo, wavy, partly ferruginated clay lamina is present (white arrows). Above this lamina, burrows are visible (green arrows). The lower part of rock under the clay laminae is strongly brecciated with clay clasts (blue arrows) and numerous elongated pores that are oval in cross-section (yellow arrows). N83 borehole, depth $241.0 \mathrm{~m}$

zons in vertisols discloses the activity of pedogenic processes (Merino and Banerjee, 2008) and the longer subaerial exposure. Evaporation of surface waters might have caused local supersaturation with respect to gypsum, and its crystallization within the sediment (e.g., Schreiber, 1988; Warren, 2006). Intense weathering during the subaerial exposure led to the generation of distinct, locally irregular boundaries of vertisols with the underlying sediments. 

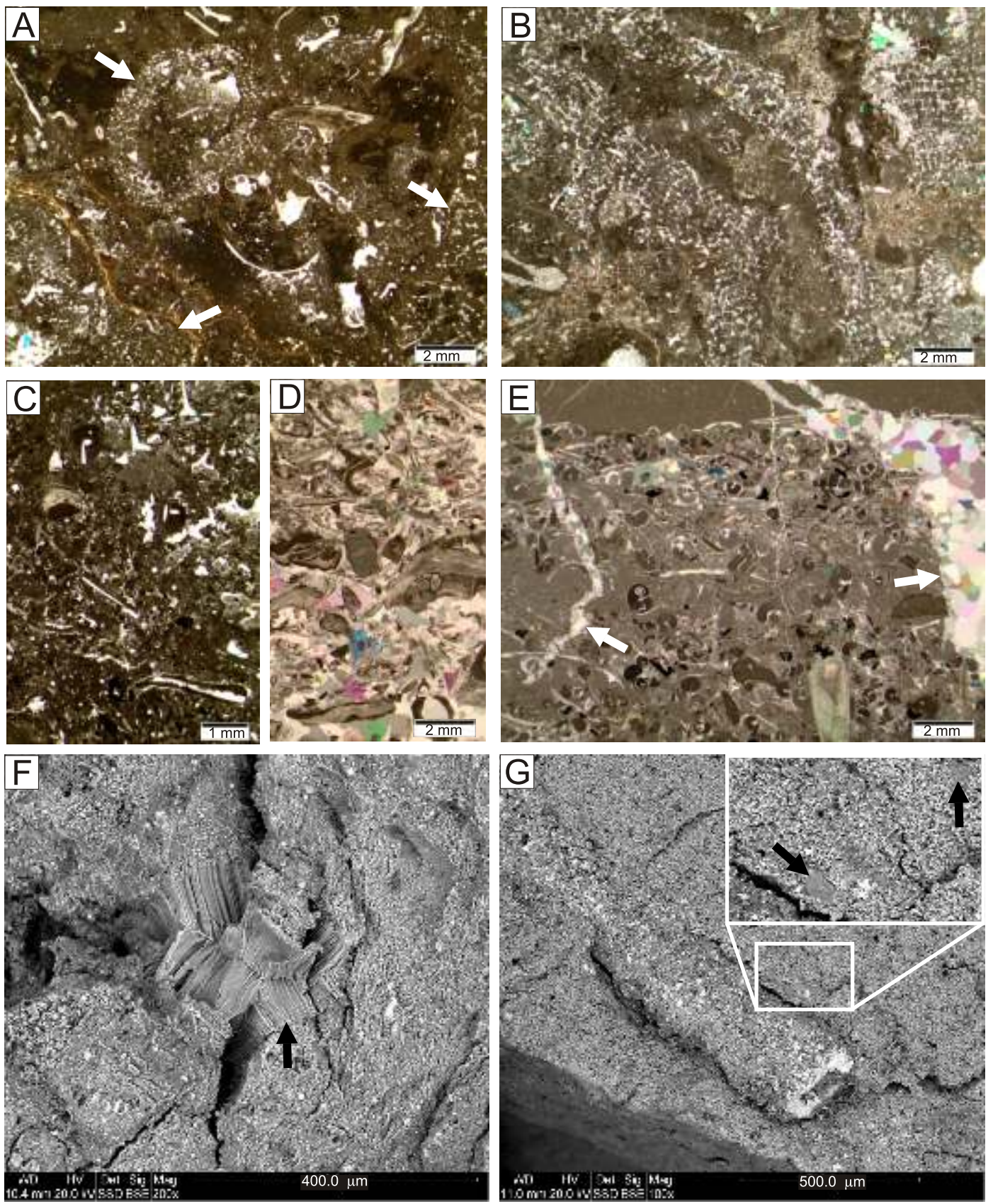

Fig. 13. Microfacies from Upper Jurassic deposits of the study area

A - sponge marly floatstone. Besides sponges (arrows) and tuberoids, numerous bivalve shells and single fragments of echinoderms and gastropods are visible. Sponge-bivalve-oncolitic limestones and marly limestones (F14). G108D borehole, depth $188.2 \mathrm{~m}$; B - sponge floatstone with irregular sponges. Sponge-bivalve-oncolitic limestones and marly limestones (F14). N71P borehole, depth $118.0 \mathrm{~m} ; \mathbf{C}$ - bioclastic wackestone with fragments of echinoderms and bivalves. Numerous sponge spicules and Saccocoma are visible. Marly limestones and marls (F17). G120D borehole, depth $135.6 \mathrm{~m}$; D - bioclastic rudstone forming a clast with numerous bivalve shells and echinoderm fragments. Uppermost part of silts, marly limestones and marls (F22). N83D borehole, depth $189.3 \mathrm{~m}$; E - gastropod laminae with wedge-shaped cracks filled with blocky calcite cement (arrows). Besides gastropods, numerous bivalves and fragments of echinoderms are present. In the uppermost part of photo, fragment of mudstone laminae is visible. Gastropod limestones (F18). A82D borehole, depth $93.0 \mathrm{~m} ; \mathbf{F}$-gypsum crystal (arrow) within clayey palaeosol. Clays, palaeosols (F21). N83D borehole, depth $240.8 \mathrm{~m}$. SEM photo; G elongated tube-shaped plant stem with pyritized outer part embedded within silt. Around the stem, numerous fine quartz grains are present (arrows). Silts, marly limestones and marls (F22). F76D borehole, depth $160.5 \mathrm{~m}$. SEM photo 


\section{SILTS, MARLY LIMESTONES} AND MARLS (F22)

The F22 facies reaches a thickness of $\sim 52 \mathrm{~m}$ (Figs. 4, 5 and Table 1). The boundary with facies F21 is sharp and horizontal. Facies F22 consists of medium- and, locally, thick-bedded greyish-green silts, commonly showing centimetre-scale fissility and intercalated with either thin- and medium-bedded marly limestones (sometimes containing abundant biodetritus) or biodetrital limestones. There are common interbeds of marls (some tens of centimetres thick) that contain abundant clasts of marly limestones (up to several centimetres in size). The bottom surfaces of marly interbeds are sharp and irregular. Immediately above such interbedding planes, larger (compared with the remaining parts of the interbeds) accumulations of clasts are observed. In the silts, burrows are common, whereas the clasts of marly limestones are rather rare. The characteristic features of silts are plentiful gypsum crystals (up to $\sim 0.5 \mathrm{~mm}$ in size) and dispersed plant detritus in the form of tubes (several millimetres long and up to $0.3 \mathrm{~mm}$ in diameter; Fig. 13G). Quartz grains also commonly occur (Fig. 13G). In the uppermost part of succession F22, there are limestone clasts full of bivalve shells, echinoderms and gastropods (Fig. 13D), embedded within the marly matrix.

Facies interpretation: the sedimentological features of F22 facies indicate their formation in a shallow environment of the ramp interior, under the changing hydrogeochemical regime. Fine, single gypsum crystals dispersed within the matrix point to interstitial crystallization from pore solutions as an effect of synsedimentary fluctuation in saturation of groundwaters. It suggests locally increased salinity of pore solutions caused by evaporation and leading to local supersaturation of the bottom waters in relation to gypsum. However, increased salinity was an episodic and short-term phenomenon that precluded deposition of large gypsum complexes. During the periods of lower salinity, the environmental conditions facilitated the growth of benthic fauna responsible for burrows in the silts. Distinct dominance of clastic sediments (silts and marls) in facies F22 and the common admixture of clay matter in the limestones may indicate the supply of terrestrial material. Clastic components, including the common admixture of terrestrial carbonified organic matter are typical of near-shore sediments (e.g., Phleger, 1969; Meyers, 1997). The subaerial exposure of adjacent areas might have facilitated both the erosion and the supply of plant detritus and quartz grains from the land, as well as the increased evaporation and crystallization of evaporitic minerals. The presence of sea currents is evidenced by erosional surfaces, limestone clasts, plant detritus and quartz grains. The erosion of various sediments is documented by limestone clasts containing abundant shell debris of bivalves, echinoderms and gastropods, which are common in the upper part of facies succession F22.

\section{REMARKS ON THE UPPER JURASSIC SEDIMENTARY SUCCESSION FROM THE KLESZCZÓW GRABEN AREA, AND CORRELATION WITH ADJACENT AREAS}

The study area is located between the regions of Poland where the Upper Jurassic sediments have been intensely investigated for decades: e.g. the Kraków-Częstochowa Upland in the south, the Barcin-Piechcin area (Kujawy region) in the north, the Mesozoic NE and SW rims of the Holy Cross Mts. in the east, the Wielun Upland in the south-west, and the Burzenin region in the west. The detailed facies studies of Upper Jurassic sediments from the southern part of the Łódź Depression (Kleszczów Graben area), located between the regions mentioned above, provided characterization of the OxfordianTithonian sedimentary succession, which is crucial for comparative studies on the Upper Jurassic sedimentary succession from central and southern Poland.

The information about the stratigraphy and lithology of Upper Jurassic sediments from the Kleszczów Graben area can be found in many papers (see e.g., Mrozek, 1975; Głowniak, 1991; Barwicz-Piskorz, 1992; Barwicz-Piskorz and Szewczyk, 1994; Krajewski et al., 2014, 2019; Wierzbowski, 2017). The Upper Jurassic sedimentary sequence from the study area is represented by lithostratigraphic formations of central Poland, distinguished by Dembowska (1979):

I - spongy-limestone,

II - limestone-marly,

IV - oolitic,

$\mathrm{V}$ - limestone-marly-coquina,

VI - shale-marly-siltstone (Pałuki),

VII - limestone-evaporitic (Kcynia) (Fig. 5).

The Upper Jurassic sedimentary succession begins at the Callovian-Oxfordian boundary, documented bio- and lithostratigraphically by Głowniak (1991) in the southern wall of the Bełchatów opencast mine. This boundary is one of the best-recognizable, distinct horizons in Europe, and documents the transition from clastic-carbonate deposition with stromatolite in the uppermost Callovian to marly-calcareous sedimentation with numerous siliceous sponges (F1) in the Oxfordian. The ammonite-based biostratigraphic datings of the spongy-limestone formation (Dembowska, 1979) from the southern part of the Łódź Depression (Kleszczów Graben area) gave the Lower-Middle Oxfordian age (Cordatum, Plicatilis and Transversarium zones; Głowniak, 1991), but it referred only to the lowermost part of the studied sequence (Fig. 5). Facies similar to F1 are known from the SW margin of Holy Cross Mts. - marly limestones (Cordatum zone) up to $6.5 \mathrm{~m}$ thick (e.g., Matyja, 1977: Głowniak, 2012), as well as from the Wieluń Upland - Jasna Góra beds (Cordatum zone), up to $14 \mathrm{~m}$ in thickness (e.g., Wierzbowski et al., 1983), which represent the lowermost part of the Częstochowa Sponge Limestone Formation in the Kraków-Częstochowa and Wieluń Uplands (cf. Matyja and Wierzbowski, 2004).

The presence of cherts, siliceous sponges, tuberoids, rare marly intercalations, and medium-thick bedding allow comparing facies F2 to the Middle Oxfordian Zawodzie Limestones exceeding a thickness of $100 \mathrm{~m}$ in the Wielun Upland (Wierzbowski et al., 1983). The Oxfordian sedimentary sequence from the study area (facies F1-F4) resembles that typical of the Kraków-Częstochowa Upland in terms of facies development and thickness of particular facies (e.g., Matyszkiewicz, 1997; Matyszkiewicz et al., 2015, 2016; Krajewski et al., 2018). Moreover, the similar to Oxfordian F1-F3 facies were described from the Kujawy region (Matyja and Wierzbowski, 1981), Mesozoic basement of the Carpathian Foredeep (e.g., Krajewski et al., 2011a; Morycowa and Moryc, 2011), Złoczew High region (e.g., Deczkowski, 1977; Krajewski et al., 2016), NE margin of the Holy Cross Mts. (e.g., Gutowski, 1998) and SW margin of the Holy Cross Mts. (e.g., Matyja, 1977). In these regions, both the massive facies and the bedded microbial-sponge facies attain thicknesses from 170 to $250 \mathrm{~m}$ and represent the spongy-limestone formation (Dembowska, 1979) and entire part of Częstochowa Sponge Limestone Formation (cf. Matyja and Wierzbowski, 2004). 
Above the Callovian/Oxfordian boundary, within the thickness interval of $\sim 180-200 \mathrm{~m}$, the bedded limestones (F2) and microbial-sponge reefs (F3) grade into the medium-bedded pelitic limestones (F5) and marly limestones and marls (F6) (Fig. 5). This succession (facies F5 and F6) is similar to the sedimentary succession described also from the surrounding regions: SW margin of the Holy Cross Mts. - transition zone between the Massive Limestones and the Siedlce Limestones, also some parts of the Siedlce Limestones (e.g., Matyja, 1977; Matyja et al., 1989), Kraków-Częstochowa Upland (Matyja and Wierzbowski, 2004; Ziółkowski, 2007; Krajewski et al., 2018), and Złoczew High (Krajewski et al., 2016). They may correspond to the limestone-marly formation in central Poland (formation No. II of Dembowska, 1979) and to the Pilica Formation from the Kraków-Częstochowa and Wieluń Uplands (Matyja and Wierzbowski, 2004; Wierzbowski, 2017).

Development and the thicknesses of Lower Kimmeridgian facies observed in the Kleszczów Graben area resemble in general those described from the SW margin of the Holy Cross Mts. (cf. Kutek, 1969; Matyja, 2011). Above the characteristic succession of pelitic limestones (F5) and marly limestones and marls (F6), the coral limestones (F7) appear (Fig. 5), which represent the coral formation (cf. Dembowska, 1979). Coral limestones grade laterally into the pelitic limestones (F7). These carbonates presumably correspond to the Chalky Limestones with pelitic limestones resembling some parts of the Siedlce Limestones (Matyja, 1977), and to the coral facies in the Chalky Limestones distinguished by Kutek (1968) (cf. Matyja, 1977, 2011). Above the coral facies (F7), Bacinella-type oncoid limestones (F8) are present, which may correspond to oncoids in the coral facies of the Chalky Limestones in the SW margin of the Holy-Cross Mts. Their diameters attain some centimetres (Kutek and Radwański, 1965; Kutek, 1968, 1969).

Above, there is a characteristic marly horizon (F9) included by Wierzbowski (2017: pages 53-54 and 61) into the Kiełczygłów Marl Member. In our opinion, based upon the analysis of sedimentary succession (also Barwicz-Piskorz, 1992) and its comparison to the SW margin of the Holy Cross Mts., these marls represent the so-called Lowermost Marly Horizon (Kutek, 1968, 1994; Matyja, 2011; Krajewski et al., 2017). This isochronous marker horizon is a key to stratigraphic correlation of Upper Jurassic deposits in central and southern Poland (Kutek, 1968, 1994). It can be traced in the SW margin of the Holy Cross Mts. (Kutek, 1968, 1994; Krajewski et al., 2017), Łódź Depression (Barwicz-Piskorz, 1992, 1995; Krajewski et al., 2014), Złoczew High (Krajewski et al., 2016), and Sulejów and Tomaszów Mazowiecki regions (Kutek, 1994). In the topmost part of the Lowermost Marly Horizon, close to the transition into the overlying oolitic facies, there is either a regionally distributed hardground (Gruszczyński, 1986; Kaźmierczak and Pszczółkowski, 1968; Matyja, 2011; Krajewski et al., 2017) or bored and encrusted clasts derived from the erosion of the hardground (Chudzikiewicz and Wieczorek, 1985; Krajewski et al., 2014, 2017).

The oolitic facies (F11) in the Kleszczów Graben area corresponds to the Lower and Upper Oolith from the SW margin of the Holy Cross Mts. (Kutek, 1968, 1969; Barwicz-Piskorz, 1992; Matyja, 2011) and to the "oolitic" formation from the northern margin of the Wieluń Upland (Kiełczygłów area) (Wierzbowski, 2017). In all these regions, these facies were classified mainly into the Hypselocyclum zone. In the study area, the top part of the oolitic facies comprises some hardgrounds. One of them separates the oolitic from oncolitic facies (Figs. 5 and 10B), as in the SW margin of the Holy Cross Mts.
("Upper Oolith/Oncolithic Horizon") (Kutek and Radwański, 1967; Kutek, 1969; Kaźmierczak and Pszczółkowski, 1968; Matyja, 2011; Krajewski et al., 2014). Also in the Radomsko Elevation (Po aryski, 1971), situated between the Łódź and Miechów depressions, oolitic limestones in the Kodrąb area are separated from the overlying oncolitic limestones by a characteristic boundary (probably hardground) with borings (Barwicz-Piskorz, 1995).

The oncolitic limestones (F12) are overlain by marls (F13), $7.5 \mathrm{~m}$ thick (Fig. 5). This marl horizon may correspond to the 12 $\mathrm{m}$ thick marls in the SW Margin of the Holy Cross Mts. (Matyja, 2011), which form the lowermost part of the Oolite-Platy Member (Kutek, 1968). Those marls correspond to the similarly thick unit $E$ in boreholes from the Szczerców-Dębina area, which was included by Wierzbowski (2017) into the "oolitic" formation of Dembowska (1979).

The interval from F13 up to middle part of F20 interval is included by the authors of this paper into the limestone-marly-coquina formation (formation No. V after Dembowska, 1979) attaining a thickness of $\sim 300$ m west of the Kleszczów Graben area (cf. Dembowska, 1979).

F14 sediments from the Kleszczów Graben area were partly erroneously interpreted as the oncolitic limestones (Szewczyk et al., 1975-2015, unpublished reports; Szewczyk and Barwicz-Piskorz, 1997; Wierzbowski, 2017). Such a mistake might have resulted from erroneous identification of debris of tubeshaped sponges (see Figs. 10C and 13A) as oncoids (oncolitic limestones unit F of the "oolitic" formation; Wierzbowski, 2017), made by previous authors (e.g., Szewczyk et al., 1975-2015, unpublished reports; Barwicz-Piskorz and Szewczyk, 1994), and from the lack of detailed sedimentological records that would enable the researchers to compile the general sedimentary succession.

The marls and marly limestones (F15), $35 \mathrm{~m}$ in thickness, are overlain by oncolitic limestones (F16) and marly limestones and marls (F17) with the total thickness of $\sim 77 \mathrm{~m}$ (Fig. 5). These sediments correspond to the Majaczewice Member of similar thickness ( $\sim 60 \mathrm{~m})$ of Burzenin Formation (Wierzbowski, 2017) and unit XX described by Mrozek (1975). Oncolitic limestones (F16) correspond to the characteristic, several metres thick oncolitic layer ("conglomeratic bed"; Premik, 1931; Kowalski, 1958) known from rare outcrops in the Burzenin region. Wierzbowski (2017) described this layer as the Brzyków Oncolithic Bed. Both a similar facies development of F16 and the $6 \mathrm{~m}$ thickness of this layer in the study area and in the Burzenin region prove that this is the same horizon. It occupies the position $\sim 30 \mathrm{~m}$ below the gastropod facies (F18) and $\sim 35 \mathrm{~m}$ over the sponge-bivalve-oncolitic limestones and marly limestones (F14) (Fig. 5). We also included the characteristic interval of 35 m thick marly limestones and marls (F17) into the Majaczewice Member (Fig. 5), which was not indicated by Wierzbowski (2017) in core PD 20B. Sediments of facies F17 were observed in every core above facies $\mathrm{F} 16$ and below facies F18 (Figs. 2-4).

Gastropod limestones with mass occurrence of tiny gastropods, intercalated with marly limestones and marls of F18, correspond to the Sarnów Gastropod Limestone Member distinguished by Wierzbowski (2017). However, the thickness of F18 $(\sim 31 \mathrm{~m})$ in our material is smaller in comparison to the thickness of the Sarnów Gastropod Limestone Member $(\sim 50 \mathrm{~m})$ in the Burzenin area and core PD 20B located south of the brown-coal mine outcrop in Dębina, where the sediments attain $\sim 50 \mathrm{~m}$ in thickness (Wierzbowski, 2017).

Facies F18 is overlain by marls, marly limestones and subordinate silts of F19, as well as by marls and marly limestones 
with abundant Nanogyra oysters (lower part of F20). These rocks were included by the present authors into the Coquina Fm. (Kutek, 1994) and into the Formation V in central Poland (Dembowska, 1979). They also correspond to the units XXIII-XXVII distinguished by Mrozek (1975) in the southern part of the Łódź Synclinorium. The position of these sediments in drill cores has not been precisely defined yet due to the lack of ammonite fauna and the insufficient precision of microfaunal dating. However, similar facies of well-bedded limestones and marls with common accumulations of Nanogyra shells yielded ammonites at Burzenin, where one of them represents the Acanthicum zone (Wierzbowski, 2017). The upper boundary of the Coquina Fm. is placed by the present authors at the top of the uppermost occurrences of Nanogyra oysters. This boundary is consistent with the upper boundary of the Coquina Formation in central Poland, where Nanogyra disappear (Kutek, 1994).

Among the studied stratigraphic units, the less known are both the Upper Kimmeridgian-Lower Tithonian Pałuki Formation (Dembowska, 1979), composed of marls and marly limestones (upper part of F20) with no distinctive lithologic marker beds (Kutek and Zeiss, 1997), and younger Upper Jurassic deposits. The thickness of the Pałuki Formation in the studied cores $(\sim 30 \mathrm{~m})$ corresponds well to the thickness $(\sim 40 \mathrm{~m})$ of the Pałuki Formation in the Bełchatów 4, 5 and 6 boreholes (Kutek and Zeiss, 1997). This formation is marked as unit XXVIII in the lithological profiles of the southern part of the Łódź Synclinorium in Mrozek (1975). In the adjacent regions, the Pałuki Formation was observed in the SW margin of the Holy Cross Mts. (see e.g., Kutek, 1968; Matyja, 2011) and in the Tomaszów Mazowiecki region (Kutek, 1994; Kutek and Zeiss, 1997; Matyja and Wierzbowski, 2014). In the SW margin of the Holy Cross Mts., deposits of the Pałuki Formation are represented by the Top Shales Formation, usually $\sim 50 \mathrm{~m}$ thick, composed of marls, marly clays and subordinate marly limestones with rare Nanogyra layers (Kutek, 1968; Matyja, 2011). In this region, the lithology of the uppermost part of the Top Shales Formation indicates a regressive trend (Matyja, 2011). Such a trend is also noted in the Kleszczów Graben area, both by numerous marly limestone clasts and erosional channels in the upper part of $\mathrm{F} 20$, and by overlying clays and palaeosols of facies F21. In the Tomaszów Mazowiecki region, the thickness of the Pałuki Formation, composed of alternating marly shales and limestones, is $150 \mathrm{~m}$ (Kutek, 1994; Kutek and Zeiss, 1997; Matyja and Wierzbowski, 2014).

Up the sequence, they grade into $\sim 50 \mathrm{~m}$ thick silts and marly limestones with fine gypsum crystals and intercalations of marls and clays (F21 and F22). These sediments are included by the present authors into the limestone-evaporitic (Kcynia) formation (formation No. VII of Dembowska, 1979) of the Lower Tithonian ("Volgian"). Deposits of the Kcynia formation in central Poland consist in general of limestones, marls and sulphates (Dembowska, 1979). The lithologic profile of $\sim 25 \mathrm{~m}$ thick Kcynia formation deposits dominated by limestones is presented by Wierzbowski et al. (2016) from the Owadów-Brzezinki Quarry located 70 km north-east from the study area. Lithology of the youngest sediments (F22) in the study area seems to correspond to the Tithonian Wieniec unit of the Kcynia formation (Dembowska, 1979; Marek et al., 1989) in which some palaeontological levels are characterized by limestones and marls with sulphates (ostracod levels D and
E) (Marek et al., 1989). We also do not rule out that the uppermost part of facies F22 represents the Lower Berriasian Skotniki Unit in which Cyrena coquinas are present (Dembowska, 1979; Marek et al., 1989). In the investigated material, we observed limestone clasts composed of numerous bivalve bioclasts (Fig. 13D).

\section{CONCLUSIONS}

In total, 22 facies were distinguished, which represent sedimentary sequences of the outer-, mid- and inner-ramp environments. These are both transgressive and regressive phases of sea level changes. The microbial-sponge, oolitic, oncolitic, gastropod, coquina, silty and marl facies were documented, typical of central Poland.

Coral facies with coral reefs, which form a distinct and separate lithologic unit, are present in the Kleszczów Graben area. This facies is lithologically similar to the coral formation and parts of some chalky limestone units in northeastern Poland and surrounding areas in central Poland.

Generally, the lower and middle parts of the sedimentary succession are carbonate-dominated (Oxfordian-Lower Kimmeridgian, Hypselocyclum zone), whereas the upper part (Upper Kimmeridgian-Tithonian) shows carbonate-siliciclastic and siliciclastic facies development.

The upper part of the sedimentary sequence comprises numerous hardgrounds, hardground clasts, tidal channel deposits and accumulations of oysters with clasts. Abundant fine gypsum crystals, plant detritus, quartz grains and local palaeosols are also characteristic.

The marly limestones and marls (F17) are a characteristic horizon present in all investigated cores in the Kleszczów Graben area, separating oncolitic limestones (F16) - a lithologic counterpart of the Brzyków Oncolite Bed in the Burzenin area, from gastropod limestones, marly limestones and marls (F18) - a lithologic counterpart of the Sarnów Gastropod Limestone Member in the Burzenin area.

The F14 facies, overlying directly the F13 marls, contains mainly sponges and sponge detritus. Oncoids are present subordinately in this facies with exception of its lowermost part, where they are more frequent compared to the rest of F14. Thus, this facies is not represented by oncolitic limestones, as is commonly presented in literature on the Kleszczów Graben area.

The sedimentary succession presented in this study may be helpful for correlation of Upper Jurassic lithostratigraphical units in central and southern Poland.

Acknowledgements. The authors are very much indebted to the staff of the Bełchatów Lignite Mine, who kindly provided materials and documentation from boreholes and gave permission to publish them. The authors are grateful to the two reviewers, A. Feldman-Olszewska and anonymous reviewer for their detailed reviews, constructive comments and suggestions that considerably improved this paper. We would like to thank $B$. Olszewska and J. Kowal-Kasprzyk for biostratigraphic data based on microfossils and T. Bajda for his help in X-ray diffraction analysis. The research was financed from the AGH-UST Grants Nos. 16.16.140.315 and 15.11.140.820. 


\section{REFERENCES}

Barwicz-Piskorz, W., 1992. Microfauna of the Upper Oxfordian and Lower Kimmeridgian sediments in the vicinity of Kodrąb (Central Poland) (in Polish with English summary). Geologia, 18: 95-115.

Barwicz-Piskorz, W., 1995. Foraminiferal Assemblages and Stratigraphy of Upper Jurassic in Holy Cross Mountains District (in Polish with English summary). Dissertations Monographies, 21. Wydawnictwa AGH, Kraków.

Barwicz-Piskorz, W., Szewczyk, E., 1994. Wpływ rozpoznania stratygrafii mezozoiku na interpretacje tektoniczne rejonu zło a Bełchatów - materiały konferencyjne (in Polish). Konferencja Naukowo-Techniczna na temat: Tektonika Rowu Kleszczowa stan badań i główne zadania w aspekcie eksploatacji górniczej, Bełchatów 20-21.10.1994: 47-62.

Bádenas, B., Aurell, M., 2010. Facies models of a shallow-water carbonate ramp based on distribution of non-skeletal grains (Kimmeridgian, Spain). Facies, 56: 89-110.

Breemen, van N., Buurman, P., 1998. Soil Formation. Kluwer Academic Publishers, Dordrecht, Netherlands.

Chudzikiewicz, L., Wieczorek, J., 1985. Bored and encrusted clasts in the Lower Kimmeridgian carbonates at Sobków (SW margin of the Holy Cross Mts., Poland). Annales Societatis Geologorum Poloniae, 55: 295-306.

Deczkowski, Z., 1977. Geology of the Permo-Mesozoic cover and its basement in the eastern part of the Fore-Sudetic Monocline (Kalisz-Częstochowa area) (in Polish with English summary). Prace Instytutu Geologicznego, 82: 1-63.

Dembowska, J., 1979. Systematization of lithostratigraphy of the Upper Jurassic in northern and central Poland (in Polish with English summary). Kwartalnik Geologiczny, 23 (3): 617-630.

Dupraz, C., Strasser, A., 1999. Microbialites and micro-encrusters in shallow coral bioherms (Middle to Late Oxfordian, Swiss Jura Mountains). Facies, 40: 101-130.

Flügel, E., 2004. Microfacies of Carbonate Rocks, Analysis, Interpretation and Application. Springer, Berlin.

Frankowiak, K., Krajewski, M., Olchowy, P., Stolarski, J., 2019. Późnojurajskie Scleractinia z centralnej Polski: koralowce strefy fotycznej czy mezofotycznej? (in Polish). In: XXIV Konferencja Naukowa Sekcji Paleontologicznej PTG, Wrocław, Długopole Górne 11-14 września 2019: 25.

Fürsich, F.T., Oschmann, W., 1986. Storm shell beds of Nanogyra virgula in the upper Jurassic of France. Neues Jahrbuch für Geologie und Paläontologie Abhandlungen, 172: 141-161.

Głowniak, E., 1991. Callovian and Oxfordian deposits from the Bełchatów open pit (in Polish with English summary). Przegląd Geologiczny, 39: 79-84.

Głowniak, E., 2012. The perisphinctid genus Prososphinctes Schindewolf (Ammonoidea, subfamily Prososphinctinae nov.): an indicator of palaeoecological changes in the Early Oxfordian Submediterranean sea of southern Poland. Neues Jahrbuch für Geologie und Paläontologie Abhandlungen, 264: 117-179.

Golonka, J., 2004. Plate tectonic evolution of the southern margin of Eurasia in the Mesozoic and Cenozoic. Tectonophysics, 381: 235-273.

Gruszczyński, M., 1986. Hardgrounds and ecological succession in the light of early diagenesis (Jurassic, Holy Cross Mts., Poland). Acta Palaeontologica Polonica, 31: 163-212.

Gutowski, J., 1998. Oxfordian and Kimmeridgian of the northeastern margin of the Holy Cross Mountains, Central Poland. Geological Quarterly, 42 (1): 59-72.

Gutowski, J., 2006. Field trip B2 - Upper Jurassic shallow water carbonate platform and open shelf facies. Introduction. In: Jurassic of Poland and adjacent Slovakian Carpathians. Field trip guidebook (eds. A. Wierzbowski et al.): 169-173. 7th International Congress on the Jurassic System, 6-18 September 2006 , Kraków, Poland.

Gutowski, J., Popadyuk, I.V., Olszewska, B., 2005. Late Jurassic-earliest Cretaceous evolution of the epicontinental sedi- mentary basin of southeastern Poland and Western Ukraine. Geological Quarterly, 49 (1): 31-44.

Insalaco, E., 1996. Upper Jurassic microsolenid biostromes of northern and central Europe: facies and depositional environment. Palaeogeography, Palaeoclimatology, Palaeoecology, 121: $169-194$.

Kaźmierczak, J., Pszczółkowski, A., 1968. Sedimentary discontinuites in the lower Kimmeridgian of the Holy Cross Mts. (in Polish with English summary). Acta Geologica Polonica, 18: 587-616.

Kershaw, S., 1994. Classification and geological significance of biostromes. Facies, 31: 81-91.

Keupp, H., Jenisch, A., Herrmann, R., Neuweiler, F., Reitner, J. 1993. Microbial crusts a key to the environmental analysis of fossil spongiolites? Facies, 29: 41-54

Kowalski, W.C., 1958. The Jurassic and Cretaceous in the western margin of the Łódź Basin in the vicinity of Burzenin along the middle course of the Warta river (in Polish with English summary). Biuletyn Instytutu Geologicznego, 143: 1-160.

Krajewski, M., Schlagintweit, F., 2018. Crescentiella-microbial-cement microframeworks in the Upper Jurassic reefs of the Crimean Peninsula. Facies, 64: 21

Krajewski, M., Matyszkiewicz, J., Król, K., Olszewska, B., 2011a. Facies of the Upper Jurassic-Lower Cretaceous deposits from the southern part of the Carpathian Foredeep basement in the Kraków-Rzeszów area (southern Poland). Annales Societatis Geologorum Poloniae, 81: 269-290.

Krajewski, M., Król, K., Olszewska, B., Felisiak, I., Skwarczek, M., 2011b. Facies of the Upper Jurassic-Lower Cretaceous sediments in the basement of the Carpathian Foredeep (Western Ukraine). Annales Societatis Geologorum Poloniae, 81: 291-307.

Krajewski, M., Olchowy, P., Felisiak, I., 2014. Lower Kimmeridgian layer with bored and encrusted hiatus concretions (Upper Jurassic, Central Poland): implications for stratigraphy and basin evolution. Annales Societatis Geologorum Poloniae, 84: 113-129.

Krajewski, M., Olchowy, P., Felisiak, I., 2016. Late Jurassic facies architecture of the Złoczew Graben: implications for evolution of the tectonic-controlled northern peri-Tethyan shelf (Upper Oxfordian- Lower Kimmeridgian, Poland). Facies, 62: 4.

Krajewski, M., Olchowy, P., Zatoń, M., Bajda, T., 2017. Kimmeridgian hardground-sequence boundary from the Mesozoic margin of the Holy Cross Mountains (central Poland): implications for the evolution of the northern Tethyan carbonate Shelf. Facies, 63: 15.

Krajewski, M., Olchowy, P., Rudziński, D., 2018. Sedimentary successions in the Middle-Upper Oxfordian reef complex from the Kraków-Częstochowa Upland (Southern Poland). Geological Quarterly, 62 (3): 653-668.

Krajewski, M., Olchowy, P., Salamon, M.A., 2019. Late Jurassic (Kimmeridgian) sea lilies (Crinoidea) from central Poland (Łódź Depression). Annales de Paléontologie, 105: 63-73.

Kutek, J., 1968. The Kimmeridgian and Uppermost Oxfordian in the SW margins of the Holy Cross Mts. (Central Poland); Part I Stratigraphy (in Polish with English summary). Acta Geologica Polonica, 18: 493-587.

Kutek, J., 1969. The Kimmeridgian and Uppermost Oxfordian in the SW margins of the Holy Cross Mts., (Central Poland); Part II Paleogeography (in Polish with English summary). Acta Geologica Polonica, 19: 221-322.

Kutek, J., 1994. Jurassic tectonic events in south-eastern Poland. Acta Geologica Polonica, 44: 167-221.

Kutek, J., Radwański, A., 1965. Upper Jurassic onkolites of the Holy Cross Mts (Central Poland). Bulletin de l'Academie Polonaise des Sciences, Série des Sciences Géologiques et Géographiques, 13: 155-159.

Kutek, J., Radwański, A., 1967. Sedimentological problems of Lower Kimmeridgian oncolitic horizon at Celiny in the Holy 
Cross Mts. (in Polish with English summary). Rocznik Polskiego Towarzystwa Geologicznego, 37: 267-272.

Kutek, J., Zeiss, A., 1997. The highest Kimmeridgian and Lowe Volgian in Central Poland; their ammonites and biostratigraphy. Acta Geologica Polonica, 47: 107-198.

Lathuilière, B., Gaillard, C., Habrant, N., Bodeur, I., Boullier, A., Enay, R., Hanzo, M., Marchand, D., Thierry, J., Werner, W., 2005. Coral zonation of an Oxfordian reef tract in the northern French Jura. Facies, 50: 545-559.

Leinfelder, R.R., Nose, M., Schmid, D.U., Werner, W., 1993. Microbial crusts of the Late Jurassic: composition, paleoecological significance and importance in reef construction. Facies, 29: 195- 230.

Leinfelder, R.R., Krautter, M., Laternser, R., Nose, M., Schmid, D.U., Schweigert, G., Werner, W., Keupp, H., Brugger, H., Herrmann, R., Rehfeld-Kiefer, U., Schroeder, J.H., Reinhold, C., Koch, R., Zeiss, A., Schweizer, V., Christmann, H., Menges, G., Luterbacher, H., 1994. The origin of Jurassic reefs: current research developments and results. Facies, 31: $1-56$.

Leinfelder, R.R., Werner, W., Nose, M., Schmid, D.U., Krautter, M., Laternser, R., Takacs, M., Hartmann, D., 1996. Paleoecology, growth parameters and dynamics of coral, sponge and microbolite reefs from the Late Jurassic. Göttinger Arbeiten zur Geologie und Paläontologie Sonderband, 2: 227-248.

Machalski, M., 1998. Oyster life positions and shell beds from the Upper Jurassic of Poland. Acta Palaeontologica Polonica, 43: 609-634.

Malinowska, L., 1967. Biostratigraphy of Lower and Middle Oxfordian deposits in the margin of the Świętokrzyskie Mountains (in Polish with English summary). Biuletyn Instytutu Geologicznego, 209: 53-112.

Marek, S., Rajska, M., Sztejn, J., 1989. New views on stratigraphy of the Jurassic-Cretaceous boundary in central Poland (Kujawy) (in Polish with English summary). Kwartalnik Geologiczny, 33 (2): 209-224.

Marcinowski, R., 1970. Turbidites in the Upper Oxfordian limestones at Jaskrów in the Polish Jura Chain. Bulletin of the Polish Academy of Sciences-Earth Sciences, 18: 219-225.

Matyja, B.A., 1977. The Oxfordian in the south-western margin of the Holy Cross Mts. Acta Geologica Polonica, 27: 41-64.

Matyja, B.A., 2009. Development of the Mid-Polish Trough versus Late Jurassic evolution in the Carpathian Foredeep area. Geological Quarterly, 53 (1): 49-62.

Matyja, B.A., 2011. Płytkowodna platforma węglanowa późnej Jury na południowo-zachodnim obrze eniu Gór Świętokrzyskich materiały do sesji terenowych (in Polish). Materiały Konferencyjne Jurassica IX, Małogoszcz, 06-08 września 2011. Polskie Towarzystwo Geologiczne, Polska Grupa Robocza Systemu Jurajskiego: 133-151.

Matyja, B.A., Wierzbowski, A., 1981. The upper Jurassic rocks at Barcin and Piechcin; their stratigraphy and facies as compared with neighbouring areas (in Polish with English summary). Kwartalnik Geologiczny, 25 (3): 513-526.

Matyja, B.A., Wierzbowski, A., 2004. Stratigraphy and facies development in the Upper Jurassic of the Kraków-Częstochowa Upland and the Wielun Upland (in Polish with English summary) In: The Diversification and Transformation of Natural and Cultural Environment of the Kraków Częstochowa Upland, 1 (ed. J. Partyka): 13-18. Ojcowski Park Narodowy, Ojców.

Matyja, B.A., Wierzbowski, A., 2014. Upper Jurassic of the Tomaszów syncline (in Polish with English summary). In: Jurajskie utwory synkliny tomaszowskiej. Jurassica XI. Przewodnik wycieczek terenowych, abstrakty i artykuły (eds. A Feldman-Olszewska and A. Wierzbowski): 9-20. Państwowy Instytut Geologiczny - PIB, Warszawa.

Matyja, B.A., Gutowski, J., Wierzbowski, A., 1989. The open shelf-carbonate platform succession at the Oxfordian/Kimmeridgian boundary in the SW margin of the Holy Cross Mts: stratigraphy, facies and ecological implications. Acta Geologica Polonica, 39: 29-48.
Matyszkiewicz, J., 1996. The significance of Saccocoma-calciturbidites for the analysis of the Polish epicontinental late Jurassic Basin: an example from the Southern Cracow-Wielun Upland (Poland). Facies, 34: 23-40.

Matyszkiewicz, J., 1997. Microfacies, sedimentation and some aspects of diagenesis of Upper Jurassic sediments from the elevated part of the Northern peri-Tethyan Shelf: a comparative study on the Lochen area (Schwäbische Alb) and the Cracow area (Cracow-Wielun Upland, Poland). Berliner Geowissenschaftliche Abhandlungen, E21: 1-111.

Matyszkiewicz, J., Krajewski, M., Kędzierski, J., 2006. Origin and evolution of an Upper Jurassic complex of carbonate buildups from Zegarowe Rocks (Kraków-Wieluń Upland, Poland). Facies, 52: 249-263.

Matyszkiewicz, J., Kochman, A., Duś, A., 2012. Influence of local sedimentary conditions on development of microbialites in the Oxfordian carbonate buildups from the southern part of the Kraków-Częstochowa Upland (south Poland). Sedimentary Geology, 263-264: 109-132.

Matyszkiewicz, J., Kochman, A., Rzepa, G., Gołębiowska, B., Krajewski, M., Gajdzik, K., aba, J., 2015. Epigenetic silicification of the Upper Oxfordian limestone in the Sokole Hills (Kraków-Częstochowa Upland): relationship to facies development and tectonics. Acta Geologica Polonica, 65: 181-203.

Matyszkiewicz, J., Krajewski, M., Kochman, A., Kozłowski, A., Duliński, M., 2016. Oxfordian neptunian dykes with brachiopods from the southern part of the Kraków-Częstochowa Upland (southern Poland) and their links to hydrothermal vents. Facies, 62: 12 .

Merino, E., Banerjee, A., 2008. Terra rossa genesis, implications for karst, and eolian dust: a geodynamic thread. Journal of Geology, 116: $62-75$

Meyers, P.A., 1997. Organic geochemical proxies of paleoceanographic, paleolimnologic, and paleoclimatic processes. Organic Geochemistry, 5-6: 213-250.

Montenat, C., Barrier, P., Ott d'Estevou, P., Hibsch, C., 2007. Seismites: an attempt at critical analysis and classification. Sedimentary Geology, 196: 5-30.

Morycowa, E., Moryc, W., 2011. Upper Jurassic-?Lower Cretaceous carbonate complex in Dąbrowa Tarnowska-Szczucin area (Carpathian Foreland) (in Polish with English summary). Biuletyn Państwowego Instytutu Geologicznego, 447: 25-48.

Mrozek, K., 1975. Budowa geologiczna struktur wgłębnych w południowej części synklinorium łódzkiego (in Polish). Wyd. Geol., Warszawa.

Neuweiler, F., Borque, P.A., Boulvain, F., 2001. Why is stromatactis so rare in Mesozoic carbonate mud mounds? Terra Nova, 13: 338-346.

Niemczycka, T., Brochwicz-Lewiński, W., 1988. Evolution of the Upper Jurassic sedimentary basin in the Polish Lowland (in Polish with English summary). Kwartalnik Geologiczny, 32 (1): 137-156.

Olchowy, P., 2011. Possible origin of stromatactis-like cavities in Upper Jurassic sediments from the Wielkanoc quarry near Gołcza (Kraków-Częstochowa Upland, southern Poland) - experimental studies. Facies, 57: 613-625.

Olóriz, F., Reolid, M., Rodríguez-Tovar, F.J., 2003. A Late Jurassic carbonate ramp colonized by sponges and benthic microbial communities (External Prebetic, Southern Spain). Palaios, 18: 528-545.

Olszewska, B., Matyszkiewicz, J., Król, K., Krajewski, M., 2012. Correlation of the Upper Jurassic-Cretaceous epicontinental sediments in southern Poland and south western Ukraine based on thin sections. Biuletyn Państwowego Instytutu Geologicznego, 453: 29-80.

Phleger, F.B., 1969. A modern evaporite deposit in Mexico. American Association of Petroleum Geologists, 53: 824-829.

Po aryski, W., 1971. The tectonics of the Radomsko elevation (in Polish with English summary). Rocznik Polskiego Towarzystwa Geologicznego, 41: 169-179.

Premik, J., 1931. Contribution à la connaissance des dépôts suprajurassiques de la chaîne de Cracovie à Wieluń et du cours 
moyen du fleuve Widawka (in Polish with French summary). Rocznik Polskiego Towarzystwa Geologicznego, 7: 133-150.

Retallack, G.J., 2001. Soils of the Past: an Introduction to Paleopedology. Blackwell, Oxford, UK.

Riding, R., 2002. Structure and composition of organic reefs and carbonate mud mounds: concepts and categories. Earth-Science Reviews, 58: 163-231.

Roniewicz, E., 2004. Jurassic corals in Poland (in Polish with English summary). Volumina Jurassica, 2: 83-97.

Roniewicz, E., Roniewicz, P., 1971. Upper Jurassic coral assemblages of the Central Polish Uplands. Acta Geologica Polonica, 21: 399-424.

Schreiber, B.C., 1988. Subaqueous Evaporite Deposition. In: Evaporites and Hydrocarbons (ed. B.C. Screiber): 182-255. Columbia University Press, New York.

Seilacher, A., 1984. Constructional morphology of bivalves: evolutionary pathways in primary versus secondary soft-bottom dwellers. Palaeontology, 27: 207-237.

Senowbari-Daryan, B., Bucur, I.I., Schlagintweit, F., Snsnran, E., Matyszkiewicz, J., 2008. Crescentiella, a new name for "Tubiphytes" morronensis CRESCENTI, 1969: an enigmatic Jurassic-Cretaceous microfossil. Geologia Croatica, 61: 185-214.

Somasundaram, J., Chaudhary, R.S., Brij Lal Lakaria, Saha, R., Sinha, N.K., Singh, R.K., Pramod Jha, Singh, R.K., Subba Rao, A., 2014. Pothole Formation and occurrence in Black Vertisols of Central and Western India. Agricultural Research, 3 87-91.

Szewczyk, E., Barwicz-Piskorz, W., 1997. Znaczenie rozpoznania litostratygrafii podło a permomezozoicznego KWB „Bełchatów” dla określenia warunków eksploatacji i potencjalnych zagro eń (in Polish). Węgiel Brunatny, 1: 29-32.

Trammer, J., 1982. Lower to Middle Oxfordian sponges of the Polish Jura. Acta Geologica Polonica, 32: 1-39.

Trammer, J., 1989. Middle to Upper Oxfordian sponges of the Polish Jura. Acta Geologica Polonica, 39: 49-91.
Védrine, S., Strasser, A., Hug, W., 2007. Oncoid growth and distribution controlled by sea-level fluctuations and climate (Late Oxfordian, Swiss Jura Mountains). Facies, 53: 535-552.

Wang, Y., Healy, T., Augustinus, P., Baba, M., Bao, C., Flemming, B., Fortes, M., Han, N., Marone, M., Mehta, A., Ke, X., Kjerfve, B., Schafer-Novelli, Y., Wolanski, E., 2002. Muddy Coasts of the World: Processes, Deposits and Function. Elsevier, Amsterdam.

Warren, J.K., 2006. Evaporites: Sediments, Resources and Hydrocarbons. Springer, Berlin.

Wierzbowski, A., 2017. The Lower Kimmeridgian of the Wielun Upland and adjoining regions in central Poland: lithostratigraphy, ammonite stratigraphy (Upper Planula/Platynota to Divisum zones), palaeogeography and climate-controlled cycles. Volumina Jurassica, 15: 1-80.

Wierzbowski, A., Matyja, B.A., Ślusarczyk-Radwan, D., 1983. New data on Upper Jurassic strata in the Wieluń Upland and vicinities of Burzenin and their economic value (in Polish with English summary). Kwartalnik Geologiczny, 27 (3): 517-533.

Wierzbowski, H., Dubicka, Z., Rychliński T., Durska, E., Olempska, E., Bła ejowski B., 2016. Depositional environment of the Owadów-Brzezinki conservation Lagerstätte (uppermost Jurassic, central Poland): evidence from microfacies analysis, microfossils and geochemical proxies. Neues Jahrbuch für Geologie und Paläontologie Abhandlungen, 282: 81-108.

Woźniak, T., Bania, G., Mościcki, W.J., Ćwiklik, M., 2018. Electrical resistivity tomography (ERT) and sedimentological analysis applied to investigation of Upper Jurassic limestones from the Krzeszowice Graben (Kraków Upland, southern Poland). Geological Quarterly, 62 (2): 287-302.

Zatoń, M., Machalski, M., 2013. Oyster-microbial rolling stones from the Upper Jurassic (Kimmeridgian) of Poland. Palaios, 28: 839-850.

Ziegler, P.A., 1990. Geological Atlas of Western and Central Europe. Shell Internationale Petroleum Maatschappij B.V.

Ziółkowski, P., 2007. Stratygrafia i zró nicowanie facjalne górnej jury wschodniej części Wy yny Krakowskiej (in Polish). Tomy Jurajskie, 4: 25-38. 